
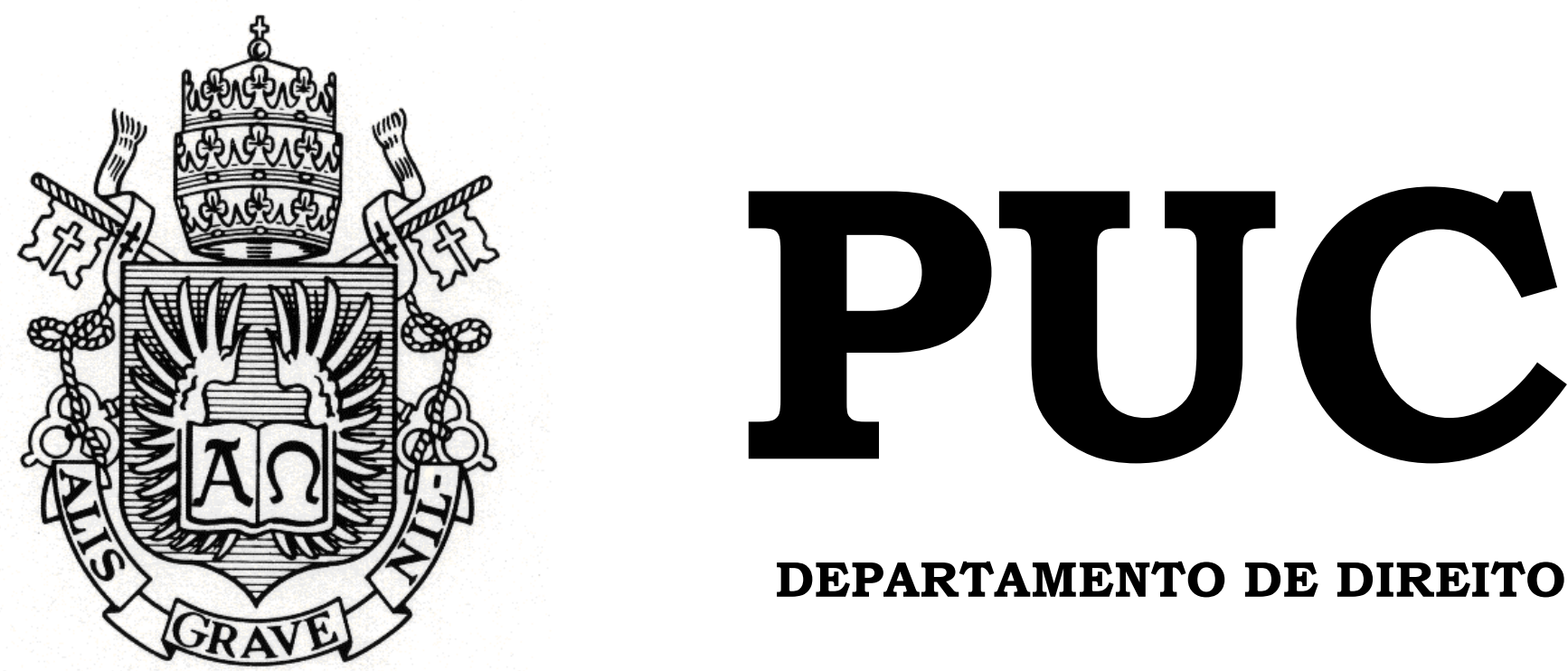

DEPARTAMENTO DE DIREITO

Microestrutura e Regime Jurídico do Mercado de Debêntures no Brasil

por

Raphael Uram

ORIENTADOR: Pablo Waldemar Renteria 2019.2

PONTIFÍCIA UNIVERSIDADE CATÓLICA DO RIO DE JANEIRO

RUA MARQUÊS DE SÃO VICENTE, 225 - CEP 22453-900

RIO DE JANEIRO - BRASIL 


\title{
Microestrutura e Regime Jurídico do Mercado de Debêntures no Brasil
}

\author{
por
}

\section{Raphael Uram}

Monografia

apresentada

ao

Departamento de Direito da Pontificia

Universidade Católica do Rio de Janeiro (PUC-Rio) para a obtenção do Título de Bacharel em Direito.

Orientador:

Pablo

Waldemar Renteria 


\section{AGRADECIMENTOS}

Agradeço, primeiramente, aos meus pais, não por terem me proporcionado uma educação formal de qualidade, mas sobretudo por terem aberto as portas de minha educação pessoal.

Em seguida, agradeço aos professores da PUC-Rio, que prezam pelo senso crítico, e estimulam a reflexão dos alunos. Em especial, agradeço ao Pablo Renteria, por ter me orientado neste trabalho.

Por fim, gostaria de agradecer à equipe da Biblioteca da PUC-Rio, que me auxiliou na obtenção de boa parte da bibliografia deste projeto, sem a qual o trabalho teria sido inviável. 


\section{RESUMO}

O presente trabalho visa a expor a forma como as negociações de debêntures, como títulos de dívida, ocorrem no Brasil. Dessa forma, analisase a trajetória histórica do instituto - debênture -, considerada desde sua primeira menção no ordenamento jurídico nacional. Assim, será exposto seu conceito, bem como suas principais características, sob a ótica jurídica. De maneira semelhante, será disposto os aspectos característicos do mercado brasileiro, conforme se reporta a literatura. Por fim, analisam-se pontos comumente atribuídos à mercados de dívida saúdaveis, e seu respectivo tratamento no Brasil.

Palavras Chave: Mercado de Dívida - Debêntures - Bonds - Microestrutura

- Regime Jurídico - Liquidez - Financiamento - Companhias - Valores Mobiliários - CVM - Mercado de Capitais. 


\section{SUMÁRIO}

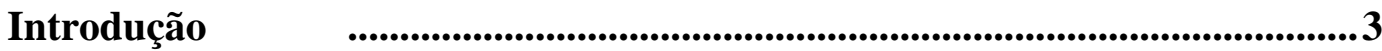

CAPÍTULO I - AS DEBÊNTURES: CONCEITO E REGULAÇÃO NO

BRASIL

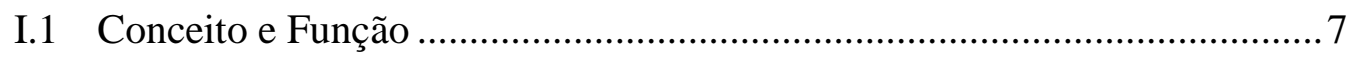

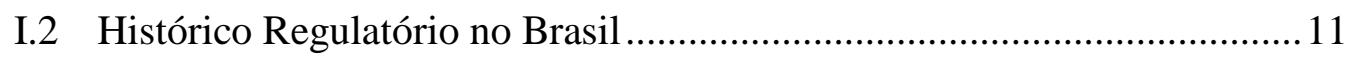

I.3 Aspectos Jurídicos das Debêntures........................................................ 14

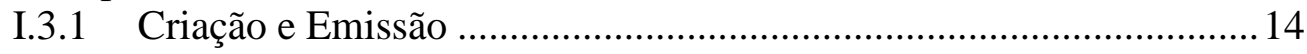

I.3.2 Espécies de Debêntures ............................................................ 18

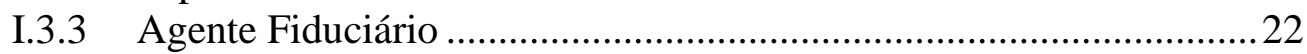

I.3.4 Vencimento, amortização e resgate ……….................................... 24

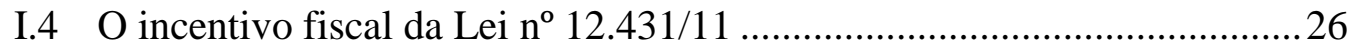

\section{CAPÍTULO II - MICROESTRUTURA DO MERCADO DE

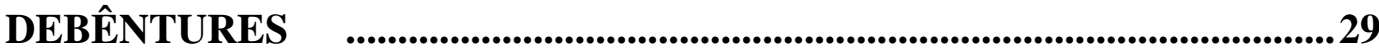

II.1. Evolução do Mercado de Debêntures ................................................... 30

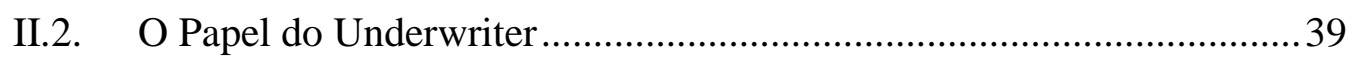

II.3. Competitividade dos Títulos Públicos................................................. 42

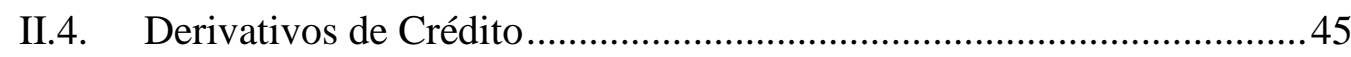

\section{CAPÍTULO III - DESAFIOS AO DESENVOLVIMENTO DO MERCADO}

DE DEBENTURES .....................................................................................49

III.1. Liquidez no Mercado Secundário de Debêntures .................................. 49

III.1.1. A relação entre Risco de Liquidez e Preço do Ativo......................51

III.1.2. Evidências de Iliquidez no Mercado Secundário de Debêntures no

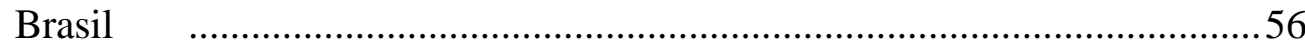

III.1.3. Comparativo com o Mercado Israelense ......................................60

III.2. Financiamento de Pequenas e Médias Empresas ..................................6 64

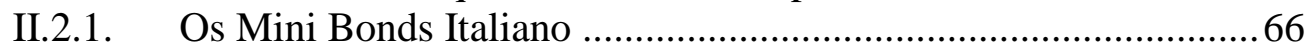

II.2.2. As Mittelstand: O caso alemão................................................ 70

Conclusão

Bibliografia $\quad$.................................................................................................................. 74 


\section{Introdução}

Não obstante parte significativa dos estudos empíricos e teóricos serem dirigidos ao mercado acionário, em cenário recente, que envolve o fortalecimento da estrutura regulatória, macroeconômica e institucional, o mercado de dívida vem ganhando destaque. Nesse aspecto, ressalta-se a importância do estabelecimento de um mercado de financiamento privado, visto se tratar de forma importante de capitalização de empresas, sobretudo em mercados emergentes ${ }^{1}$.

Nessa direção, a International Organization of Securities Comissions $\mathrm{IOSCO}^{2}$-, destaca que mercados de dívida robustos contribuem para a estabilidade econômica e funcionam como alternativa à dependência do crédito bancário, diversificando as alternativas de financiamento no mercado. Dessa forma, discute-se, na literatura, o modelo mais eficiente, predominantemente bancário ou modelo de mercado (market-based).

De todo modo, fato é que, em um plano descentralizado, qual seja a estrutura do mercado de capitais, reduz-se a significância de um conjunto específico de instituições, importante na lógica de riscos sistêmicos.

Em perspectiva global, o mercado brasileiro está em crescimento, sendo classificado como emergente ${ }^{3}$. Assim, pode-se observar, no Gráfico 1, a relação entre o Produto Interno Bruto (PIB) e o estoque total do mercado, no qual se sobressai a relevância do mercado de dívida, em cada economia.

\footnotetext{
1 "Since the mid-1990s, corporate bond markets have become an increasingly important source of financing for the private sector, especially in the emerging market countries. The authorities in these countries are becoming increasingly aware of the importance of establishing deep, liquid corporate debt markets and have placed such development high on their agenda. To date, corporate bond markets in many countries remain largely underdeveloped, with a limited supply of quality issues and inadequate market infrastructure. Even in mature market countries, such as the United States and Europe, secondary markets for corporate bonds are relatively illiquid for the majority of bond issues, in the same manner that liquidity in government securities markets is usually limited to a few benchmark issues (Schinasi and Smith, 1998)." LUENGNARUEMITCHAI, Pipat; ONG, Li Lian. An Anatomy of Corporate Bond Markets: Growing Pains and Knowledge Gains. IMF Working Paper WP/05/152. EUA: IMF, 2005. p, 3.

2 INTERNATIONAL ORGANIZATION OF SECURITIES COMMISSIONS. Development of Corporate Bond Markets in the Emerging Markets. Espanha: IOSCO, 2011. p, 5.

${ }^{3}$ Ibid,, p, 11.
} 
Gráfico 1 - Dimensão do Mercado (em \% PIB)

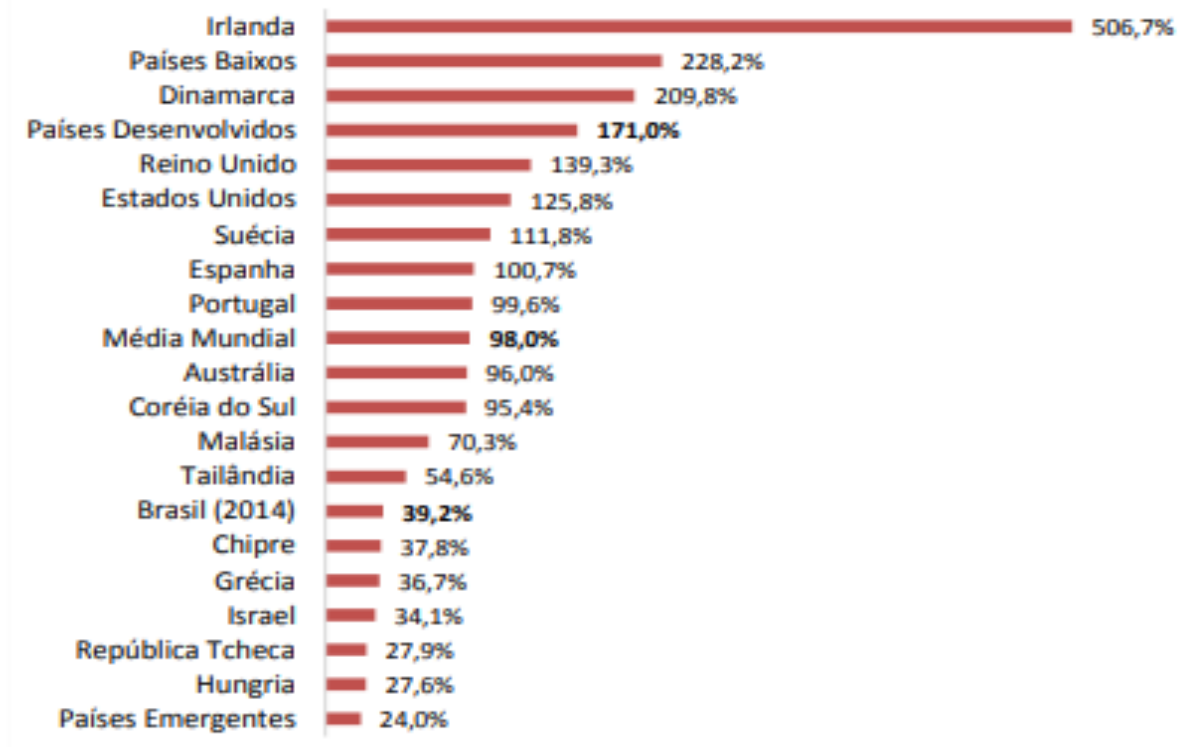

Fonte: Comissão de Valores Mobiliários

Dessa forma, nota-se que o Brasil tem, ainda, tem baixa participação no mercado global de dívida, estando significativamente abaixo da média dos países desenvolvidos e da média global (171\% e 98\%, respectivamente). Contudo, relativamente aos países emergentes, no qual o volume total do mercado é de 5,6 trilhões de dólares ${ }^{4}$, o Brasil apresenta desempenho relativamente positivo, o que demonstra o potencial da indústria.

Conforme projeção realizada pela $\mathrm{IOSCO}^{5}$, o crescimento econômico constante, o controle inflacionário e a estabilidade macroeconômica das economias emergentes evidenciam que há espaço para o desenvolvimento do mercado de dívida corporativa nos países em desenvolvimento. Dessa forma, observa-se no Gráfico 2 o aumento de importância dos países emergentes, que podem alcançar até $40 \%$ do mercado até 2050 .

No âmbito nacional, a Comissão de Valores Mobiliários (CVM) ${ }^{6}$ divulgou estudo no qual avalia o desempenho do mercado de dívida

\footnotetext{
${ }^{4}$ INTERNATIONAL ORGANIZATION OF SECURITIES COMMISSIONS. Op. Cit., p, 11.

${ }^{5}$ Ibid. p, 7.

${ }^{6}$ COMISSÃO DE VALORES MOBILIÁRIOS. Op. Cit., 1.
} 
brasileiro, e elenca medidas para sua maturação. Nesse quadro, nota-se o empenho para o desenvolvimento de uma indústria nacional competitiva.

Gráfico 2- Projeção de Evolução do Mercado de Dívida (em USD bilhão, 2007)

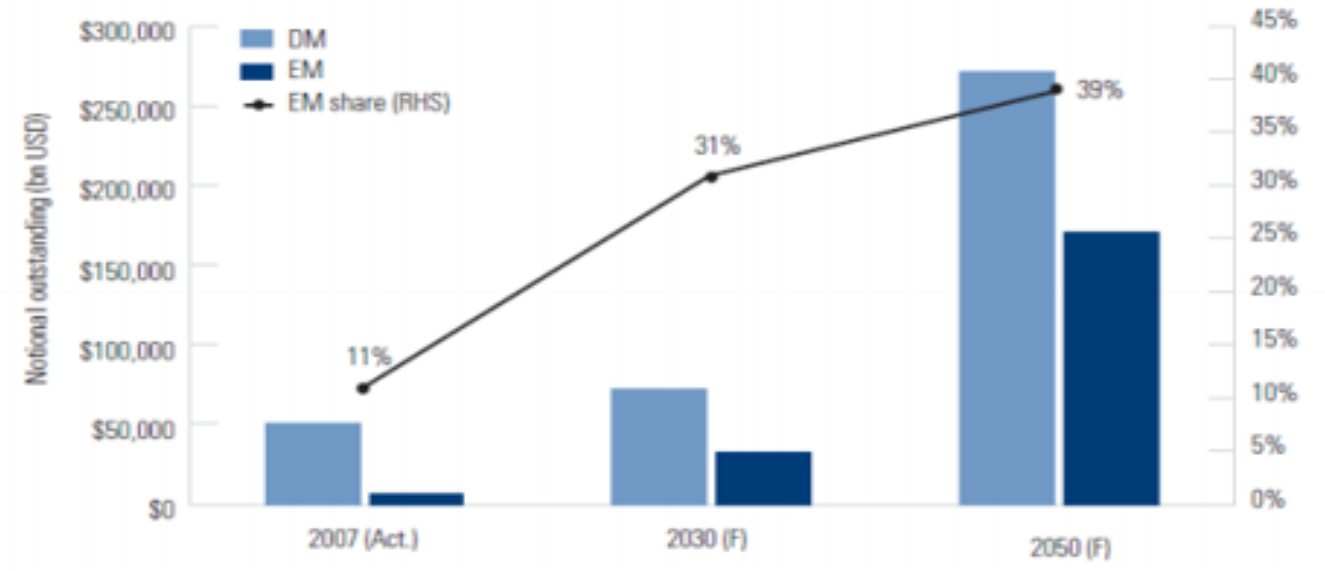

Fonte: IOSCO

Não obstante a iniciativa da CVM, não há reporte, na literatura, da vinculação do crescimento do mercado a um incentivo regulatório e institucional, sendo mais comumente associado a um conjunto de fatores que tangenciam o campo do Direito. Dessa forma, ganha relevância o estudo multidisciplinar sobre o tema, abordando, inclusive, o contexto internacional.

Em dados divulgados pela CVM, nota-se a predominância das debêntures entre os instrumentos de dívida emitidos no Brasil ${ }^{7}$. Segundo as informações divulgadas pela autarquia, as debêntures representam cerca de $63 \%$ do montante total captado em emissões de dívida privada entre 2011 e 2018, no Brasil.

Ressalta-se, dessa forma, a preocupação do regulador e do mercado no desenvolvimento de um mercado de dívida. Nesse impulso, a CVM realizou entrevistas com participantes de mercado e estudos empíricos, de modo contribuir à discussão, ficando evidente, assim, o espaço para desenvolvimento do mercado.

Destaca-se, assim, a necessidade de empenho no estabelecimento de um mercado secundário líquido, ponto comumente atribuído a estruturas

\footnotetext{
${ }^{7}$ Como, por exemplo, Notas Promissórias, Certificados de Recebíveis Imobiliários (CRI), Fundos de Investimento Imobiliário (FIDC), Certificados de Recebíveis do Agronegócio (CRA) e Letras Financeiras.
} 
desenvolvidas. Semelhantemente, há demanda à inovação no mercado, incluindo, entre outras coisas, formas de pequenas e médias empresas acessarem o mercado de dívida em busca de financiamento, e elaboração de novos produtos.

Quanto ao último ponto, a experiência europeia demonstra o estabelecimento de mercados de mini-bonds, dito assim instrumentos de dívida emitidos por companhias de porte limitado. Nesse caso, deve-se menção, sobretudo ao sucesso da experiência italiana, ao facilitar a criação de um mercado, nestes termos, conforme será analisado abaixo.

Pelo exposto, o presente trabalho analisará o mercado de debêntures brasileiro, visto que este é o instrumento de dívida com maior representatividade nas emissões domésticas. Busca-se, assim, elucidar a forma como se prática o financiamento por meio de aludido título de dívida, bem como fornecer arcabouço teórico com o objetivo de contribuir para o desenvolvimento regulatório brasileiro.

Assim, no Capítulo 1 se analisará a regulação jurídica das debêntures, de forma ampla. Nesse ponto, serão abordadas as hipóteses de utilização do instrumento e o panorama geral ao qual ele se insere, tendo como premissa o fato de que o regime legal estabelece limitações práticas a atuação no mercado.

No Capítulo 2, será exposta a estrutura do mercado de debêntures no Brasil, buscando quantitativamente e qualitativamente elucidar as principais formas de emprego das debêntures. Da mesma forma, serão expostas algumas formas de atuação no mercado global.

E, por fim, no Capítulo 3 serão abordadas algumas demandas institucionais mencionadas em estudos sobre o mercado de debêntures no Brasil. Assim, será analisada a importância e o impacto da liquidez no mercado de debêntures, bem como a questão do financiamento de pequenas e médias empresas. 


\section{CAPÍTULO I- AS DEBÊNTURES: CONCEITO E REGULAÇÃO NO BRASIL}

As debêntures, conforme se precisará abaixo, são instrumentos de dívida essencialmente de longo $\operatorname{prazo}^{8}$. Nesses termos, seu regramento jurídico remonta à década de 1.860, quando fez-se a primeira menção a instrumento de dívida emitido por sociedades por ação.

A evolução das práticas de mercado, contudo, tornaram a regulação sobre a matéria significativamente mais rebuscada. Desse fato, nota-se o regime estabelecido pela Lei n” 6.404, de 15 de dezembro de 1976 ("Lei n 6.404/76" ou "LSA"), e suas posteriores alterações.

Assim, de forma a introduzir o título de dívida propriamente dito, para em seguida delimitar seu mercado de atuação (Capítulo 2), faz-se necessário dispor sobre o regime jurídico das debêntures. Nesse primeiro momento, se precisará o conceito de debêntures, bem como sua função econômica (item $1)$.

Em seguida, serão expostas as principais características das debêntures, segundo a LSA (item 2). E, por fim, se desenvolverá a lógica das debêntures incentivadas, importantes para o funcionamento do mercado atual (item 3).

\section{I.1 Conceito e Função}

Tanto a teoria jurídica quanto a econômica tratam da conceituação da debênture, sendo certo que esta constitui, por definição, modalidade de título de dívida. Nessa linha, nota-se que, a priori, a debênture é instrumento hábil para incorporação de obrigação creditícia de uma companhia ${ }^{9}$.

Para o emissor, a emissão de dívida torna-se relevante uma vez que permite a captação de recursos sem alteração de sua estrutura societária, constituindo capital de terceiros. Por outro lado, uma sociedade saudável

\footnotetext{
${ }^{8}$ ASSAF NETO, Alexandre. Mercado Financeiro. 14 Edição. São Paulo: Atlas, 2019. p, 86.

9 LAMY FILHO, Alfredo e BULHÕES PEDREIRA, José Luiz (Coor.). Direito das Companhias. $2^{\mathrm{a}}$ Edição. Rio de Janeiro: Editora Forense, 2017. p, 425.
} 
financeiramente também necessita apresentar um nível de endividamento razoável, o qual tem repercussão em sua estrutura de capital, tema amplamente teorizado ${ }^{10}$.

As debêntures se diferenciam das ações, nesse ponto, na medida em que as últimas constituem títulos de participação, atribuindo a qualidade de acionista ao seu titular, incorrendo no risco do empreendimento. Em contrapartida, o pagamento das debêntures constitui uma obrigação da sociedade, contabilizada em seu passivo, de modo que o debenturista é credor da companhia emissora, podendo, inclusive, executar a sociedade em caso de inadimplemento.

Em regra, ainda, a ação é classificada como renda variável, ante a necessidade de apuração de lucro para distribuição de dividendos. A debênture, por sua vez, é referida como renda fixa, pois faz jus a pagamento periódico, nos termos da escritura de emissão, sujeito a uma dada taxa de juros, independente do resultado da companhia.

Preliminarmente, ainda, deve-se uma distinção, de ordem prática, entre os termos debêntures e bond (em inglês). Bond é a forma com que boa parte da literatura estrangeira se refere ao instrumento de dívida. De todo modo, faz-se a ressalva que bond e debênture não se reportam exatamente ao mesmo fenômeno.

Assim, na prática americana, bond é o gênero pelo qual são tratados diversos instrumentos de dívida, como: corporate bond, government bond $\mathrm{e}$ municipal bond. Ainda na literatura americana, debenture é considerada a modalidade de financiamento não garantida por nenhum ativo específico, mas só pelo patrimônio geral do emissor ${ }^{111213}$.

\footnotetext{
${ }^{10}$ MODIGLIANI, Franco; MILLER, Merton H. The Cost of Capital, Corporation Finance and Theory of Investment. The American Economic Review Vol. 48, No 3. EUA: 1958.

11 AMARAL, José Romeu Garcia do. Ensaios sobre o Regime Jurídico das Debêntures. Faculdade de Direito da Universidade de São Paulo. Dissertação de Mestrado. 2014. p, 21.

12 Visto a intercambialidade dos termos, utiliza-se, neste trabalho, bond como o sinônimo de debênture.

${ }^{13}$ Como cita LEÃES, em referência à célebre decisão inglesa de 1870: "I hold that under these debentures they (the debenture-holders) have a charge upon all property of the company, past and future, by the term "undertaking", and they stand in a position superior to that of the general
} 
Dessa forma, reporta-se à teoria financeira para melhor compreender o conceito do instrumento. FABOZZI ${ }^{14}$ determina que um bond seria:

\begin{abstract}
"A bond is a debt instrument requiring the issuer (also called the debtor or borrower) to repay to the lender/investor the amount borrowed plus interest over a specific period of time. A typical ("plain vanilla") bond issued in the United States specifes (1) a fixed date when the amount borrowed (the principal) is due, and (2) the contractual amount of interest, which typically is paid every six months. The date on which the principal is required is called the maturity date. Assuming that the issuer does not default or redeem the issue prior the maturity date, an investor holding this bond until the maturity date is assured a known cash flow pattern."
\end{abstract}

Da definição de FABOZZI, extrai-se a noção do empréstimo debenturístico, no qual uma companhia recebe um valor principal mutuado, e se obriga a pagá-lo em determinada data, acrescida de juros, que segundo a dinâmica da LSA, pode ser pré ou pós fixado, contar com um percentual pré fixado e outro pós fixado, ou ainda se dar mediante participação nos lucros ${ }^{15}$. Ainda, traz-se uma definição interessante, maturity, sendo essa a data no qual o principal é pago ${ }^{16}$.

$\mathrm{Na}$ teoria jurídica, sob outra ótica, a classificação do instrumento é dada visto sua natureza. Em linhas gerais, assim, debênture seria o valor mobiliário capaz de conferir crédito contra companhia emissora. FRANCISCO JOSÉ PINHEIRO GUIMARÃES, em o Direito das Companhias, explica a função das debêntures:

creditors, who can touch nothing until they are paid". LEÃES, Luiz Gastão Paes de Barros. Estudos e Pareceres sobre Sociedades Anônimas. São Paulo: Editora Revista dos Tribunais, p. 88, 1989.

${ }^{14}$ FABOZZI, F.J. Bond Markets, Analysis and Strategies. Prentice-Hall, Inc. 3rd Edition, New Jersey. 1996. p,1.

15 “A debênture pode assegurar ao seu titular, além dos juros, fixos ou variáveis, participação no lucro da companhia ou apenas essa modalidade de rendimento. A debênture a qual é atribuída apenas participação no lucro da companhia, tem um rendimento eventual e incerto, vinculado à existência de lucro. É sobre o lucro do exercício que será apurada a participação das debêntures, observados o percentual e as condições constantes da escritura de emissão." EIZIRIK, Nelson. A Lei das S/A Comentada - Volume Um. $2^{\mathrm{a}}$ Edição. São Paulo: Quartier Latin, 2015, p, 388.

${ }^{16}$ Alexandre Assaf Neto define debênture como: "Debêntures são títulos de dívida de longo prazo emitidos por sociedade por ações e destinados, geralmente, ao financiamento de projetos de investimentos (fixo e giro) ou para alongamento do perfil de endividamento das empresas. Constituise, em essência, num instrumento no qual o tomador de recursos (emitente do título) promete pagar ao aplicador (debenturista) o capital investido, acrescido de juros, em determinada data previamente acertada" ASSAF NETO, Alexandre. Mercado Financeiro. 14ª Edição. São Paulo: Atlas, 2019. p, 86. 
“A função precípua das debêntures é servir de instrumento nas trocas que processam no mercado de capitais entre a companhia e os agentes que dispõem de poupanças para investir: a companhia emite debêntures que entrega aos investidores recebendo em troca recursos, que aplicará para os fins constantes da escritura de emissão. Esta escritura estipula o vencimento, a taxa de juros e demais condições das debêntures. $\mathrm{Na}$ sua função de instrumento de troca por capital de empréstimo a debênture é necessariamente - título de prazo médio ou longo." ${ }^{17}$

Ponto recorrente na doutrina jurídica, ainda, é a classificação como negócio de mútuo. Fato é, contudo, que a LSA não faz referência a essa qualidade, somente se referindo a debênture como valor mobiliário. Dessa forma, admitem-se casos em que a debênture não teria finalidade mutuária ${ }^{18}$.

Dessa forma, deve-se notar que, sendo a debênture um título de dívida contra o emissor, usualmente se pressupõe a existência de um negócio subjacente que irá justificar sua emissão. Recorrentemente, as debêntures são emitidas como forma de financiamento, o que implica em uma operação de mútuo, e justifica a referência doutrinária, nesse ponto.

Contudo, a debênture é um instrumento jurídico extremamente versátil, visto suas características que serão abordadas abaixo. Assim, não se pode restringir seu campo de atuação às operações de mútuo.

No regime vigente, portanto, considerando a classificação das debêntures como valor mobiliário, faz-se uma abstração da causa de emissão deste ativo. Logo, não se exige um nexo causal entre a emissão de uma debênture e um negócio jurídico específico, que o dê causa.

Nessa lógica, conforme definido por FRANCISCO JOSÉ PINHEIRO GUIMARÃES, classifica-se debênture tão somente como: “valor mobiliário que confere ao seu titular direito de crédito contra a companhia emissora nas

\footnotetext{
${ }^{17}$ LAMY FILHO, Alfredo e BULHÕES PEDREIRA, José Luiz (Coor.). Direito das Companhias. $2^{\mathrm{a}}$ Edição. Rio de Janeiro: Editora Forense, 2017. p, 425.

${ }^{18}$ Nesse ponto, defende Otávio Yazbek: “Como lembra Leães (1978, p.08 e ss.), porém, a relação jurídica que dá causa à emissão pode mesmo ter outra natureza que não a de mútuo, o que cria a possibilidade de utilização das debêntures também em outras relações (como, por exemplo, para "securitizar" dívidas já existentes, em eventual renegociação". YAZBEK, Otávio. Regulação do Mercado Financeiro e de Capitais. Rio de Janeiro: Elsevier, 2017. p. 96.
} 
condições constantes na escritura de emissão"19. Não se deve, portanto, pressupor sua classificação a um negócio jurídico causal específico.

\section{I.2 Histórico Regulatório no Brasil}

Feitas essas considerações, cabe a disposição sobre a trajetória regulatória das debêntures no Direito brasileiro. Nesse ponto, busca-se a exposição da evolução do instrumento jurídico, na medida em que se adapta às condições de mercado.

A primeira forma que se tem notícia da introdução de instrumento de dívida emitida por sociedades por ações, no Brasil, remonta à Lei $n^{\circ} 1.083$, de 22 de agosto de $1860^{20}$. De acordo com esse diploma legal, sociedades por ações podiam emitir notas ou bilhetes ao portador contra o caixa da própria sociedade $^{21}$.

Nota-se, ainda, nesse primeiro momento, que a emissão de títulos de dívida pela sociedade dependia de prévia autorização pelo poder legislativo, salvo se realizado por instituições financeiras criadas pelo poder executivo. JOSÉ ROMEU GARCIA DO AMARAL ${ }^{22}$ demonstra que este mecanismo

\footnotetext{
${ }^{19}$ GUIMARÃES, Francisco José Pinheiro. Debêntures. In: LAMY FILHO, Alfredo e BULHÕES PEDREIRA, José Luiz (Coord.). Direito das Companhias. $2^{\mathrm{a}}$ Edição. Rio de Janeiro: Editora Forense, 2017. p, 421.

$20{ }^{20}$ CARVAlHOSA, Modesto. Comentários à Lei de Sociedades Anônimas - $1^{\circ}$ Volume. 5a Edição. São Paulo: Saraiva, 2007. p. 563.

21 “Art. $1^{\circ}$ Nenhum dos Bancos creados por Decretos do Poder Executivo poderá emittir, sob a fórma de notas ou bilhetes ao portador, quantia superior ao termo médio de sua emissão operada no decurso do primeiro semestre do corrente anno, emquanto não estiver habilitado para realisar em ouro o pagamento de suas notas; excepto se, além do fundo disponível ou de garantia e das outras condições estabelecidas nos respectivos estatutos, tiver em caixa parte de seu capital equivalente ao excesso do dito termo médio de emissão, e fôr esta parte representada por moeda de ouro ou barras do mesmo metal do toque de vinte dous quilates, ou por barras de prata de onze dinheiros na relação fixada pelo art. $3^{\circ}$ do Decreto $n^{\circ} 1.721$ de 5 de Fevereiro de 1856, com tanto que o valor destas não exceda á quarta parte do da moeda e barras de ouro.

$\S 10$. Nenhum Banco, que não fôr dos actualmente estabelecidos por Decretos do Poder Executivo, Companhia ou Sociedade de qualquer natureza, commerciante ou individuo de qualquer condição, poderá emittir, sem autorisação do poder Legislativo, notas, bilhetes, vales, papel ou titulo algum ao portador, ou com o nome deste em branco, sob pena de multa do quadruplo do seu valor, a qual recahirá integralmente tanto sobre o que emittir como sobre o portador."

${ }^{22}$ AMARAL, José Romeu Garcia do. Ensaios sobre o Regime Jurídico das Debêntures. Faculdade de Direito da Universidade de São Paulo. Dissertação de Mestrado. 2014. p, 12.
} 
foi utilizado pelo governo da época, visto a divergência acerca da condução da política econômica e cambial, como se expõe:

\begin{abstract}
"A restrição imposta pela Império, por meio da Lei n ${ }^{\circ} 1.083$, tinha como pano de fundo a divergência sobre a condução da política econômica e cambial do país, publicamente difundida entre o presidente do Banco do Brasil, Visconde de Itaboraí (defensor do padrão ouro), e o Ministro da Fazenda, Souza Franco (adepto da liberação do crédito e da livre iniciativa), com a participação do Barão de Mauá que, após perder o Banco do Brasil para o governo, decidiu fundar uma sociedade em comandita com a emissão de ações ao portador."
\end{abstract}

Em 4 de novembro de 1882, a partir da promulgação da Lei $\mathrm{n}^{\circ} 3.150$ por Dom Pedro II, foi estatuído regime no qual autorizava-se a emissão de obrigações ao portador, de forma a possibilitar a sociedade a contrair empréstimos, via emissão de títulos de dívida, junto ao público geral. Nessa nota, a Lei $\mathrm{n}^{\mathrm{o}} 3.150 / 1882$ trouxe inovações interessantes, como a possibilidade de nomeação de um fiscal (agente fiduciário), que teria a função de dar pareceres sobre os negócios e operações do exercício seguinte.

No mesmo ano, foi-se utilizado pela primeira vez, no ordenamento jurídico brasileiro, o vocábulo debênture. Assim, o termo foi relacionado no Decreto $\mathrm{n}^{\circ} 8.821$, de 30 de dezembro de 1.882 , entre parênteses, em medida que autorizava as companhias a contrair empréstimos por obrigações ao portador ("art. 21. É permittido às sociedades anonymas contrahir emprestimo por via de obrigações (debentures) ao portador").

Já no regime republicano, foram editados decretos que, em linhas gerais, replicam o conteúdo acima citado, referindo-se à debênture como obrigação ao portador expedida por sociedades anônimas ou em comandita de ações. Interessante ressaltar, nesse movimento legislativo, o Decreto $\mathrm{n}^{\circ} 2.519$, de 22 de maio de 1.897, que admitiu a possibilidade de reunião de debenturistas, com o intuito de discutir propostas da companhia emissora, e o Decreto $\mathrm{n}^{\circ}$ 177-A, de 25 de novembro de 1.893 ("Decreto $\mathrm{n}^{\circ} 177-\mathrm{A}$ "), que trouxe inovações como a obrigatoriedade de anúncio de distribuição, igualdade de direitos entre os debenturistas, registro da escritura de emissão em cartório, debêntures conversíveis e publicação periódica das demonstrações 
financeiras, além de tratar as debêntures ${ }^{23}$, de maneira geral, da seguinte forma:

\begin{abstract}
"Art. $1^{\circ}$ As companhias ou sociedades anonymas poderão emittir emprestimos em obrigações ao portador (debentures), de conformidade com o disposto nesta lei.

$\S 1^{\circ}$ As obrigações que as sociedades anonymas emittirem terão por fiança todo o activo e bens de cada companhia, preferindo a outros quaesquer titulos de divida.

I. Liquidando-se a sociedade, os portadores dessas obrigações (obrigacionistas) serão pagos antes de quaesquer outros credores, os quaes não serão admittidos sinão depois de recolhidas todas ellas, ou depositado o seu valor.

II. A preferencia assegurada aos obrigacionistas não prejudica aos credores hypothecarios, antichresistas e pignoraticios, quanto ás hypothecas, ás antichreses e aos penhores anterior e regularmente inscriptos."
\end{abstract}

Nota-se, até esse momento, que a lei fazia menção à possibilidade de sociedades anônimas contraírem empréstimos, via debênture. Dessa forma, se falava em título causal, visto que deveria estar atrelada a negócio jurídico subjacente de empréstimo.

Já no século XX, anteriormente à promulgação da Lei $n^{\circ} 6.385$, de 7 de dezembro de 1976 ("Lei n $\left.{ }^{\circ} 6.385 / 76 ”\right)$, o referido instrumento era regido pela Lei $\mathrm{n}^{\circ} 4.728$, de 14 de agosto de 1965 (“Lei $\mathrm{n}^{\circ} 4.728 / 65$ ”), e pelo Decreto $\mathrm{n}^{\circ}$ 177-A. Dessa forma, a Lei $n^{\circ} 4.728 / 65$, em sua vigência, estabelecia as debêntures nominativas e endossáveis, criou as cláusulas de correção monetária e instituiu registro no Banco Central, em se tratando de ofertas públicas para negociação em mercado de bolsa e de balcão.

No ano de 1976, pela promulgação da Lei n ${ }^{\circ} 6.385 / 76$ e da LSA, todavia, foram introduzidas no sistema jurídico nacional grande parte das normas que disciplinam atualmente as debêntures. Assim, de partida, conforme será descrito abaixo, destaca-se a caracterização das debêntures como valores mobiliários, por definição do artigo $2^{\circ}$ da Lei $n^{\circ}$ 6.385/76. Tal definição, nesse paradigma, torna-se sobretudo relevante para fundamentação de sua negociabilidade e circulação em mercados organizados, sendo classificadas como "títulos de massa"24.

\footnotetext{
${ }^{23}$ GUIMARÃES, Francisco José Pinheiro. Debêntures. In: LAMY FILHO, Alfredo e BULHÕES PEDREIRA, José Luiz (Coord.). Direito das Companhias. $2^{\text {a }}$ Edição. Rio de Janeiro: Editora Forense, 2017. p, 421.

${ }^{24}$ LAMY FILHO, Alfredo e BULHÕES PEDREIRA, José Luiz (Coord.). Op. Cit.,. p, 378.
} 


\section{I.3 Aspectos Jurídicos das Debêntures}

Pelo que se expõe, passa-se, a seguir, a descrever as características jurídicas das debêntures. Assim, visto que a debênture constitui instrumento privativo da sociedade anônima, sua constituição normativa é tida em vista à Lei no 6.404/76, conforme suas modificações.

Assim, as debêntures podem ser simples ou conversíveis em ações. Sendo as primeiras exclusivamente títulos de dívidas, sem qualquer modalidade de participação, enquanto as segundas, nos termos da escritura, podem conferir ao debenturista a faculdade de converter suas debêntures em ações, atendidas certas condições ${ }^{25}$.

\section{I.3.1 Criação e Emissão}

Inicia-se, portanto, a disposição jurídica das debêntures com o ato de criação, no sentido inovativo, de colocação no mercado um ativo anteriormente inexistente. Assim, pelo que a debênture é um instrumento privativo das sociedades anônimas, exige-se um procedimento próprio para criação e emissão, sobretudo no que tange à competência para deliberar sobre a matéria.

Convém, de partida, distinguir o ato de emissão do ato de subscrição. Enquanto o primeiro constitui iniciativa da companhia, deliberando e criando o instrumento jurídico, o segundo é o negócio jurídico pelo qual um investidor se torna debenturista, aceitando as condições estabelecidas na escritura de emissão. Nesse ponto, leciona NELSON EIZIRIK:

"Distingue-se, no negócio jurídico da debênture, duas fases: a da emissão, propriamente dita, na qual produz-se uma manifestação de vontade da companhia, necessariamente formada de acordo com as normas legais e estatutárias, cujo momento essencial é o da deliberação da Assembléia Geral que autoriza a emissão e

\footnotetext{
25 “A debênture conversível permite à companhia captar recursos sem a necessidade de emitir imediatamente ações representativas de seu capital e, face à opção que tem o debenturista de se manter titular das debêntures até o vencimento ou convertê-las em ações, a companhia pode praticar taxa de juros mais baixas comparativamente aos juros das debêntures simples". EIZIRIK, Nelson. A Lei das S/A Comentada - Volume Um. $2^{\mathrm{a}}$ Edição. São Paulo: Quartier Latin, 2015, p, 392.
} 
estabelece as suas características; e a da subscrição, na qual os tomadores do título manifestam sua aceitação à oferta da companhia emissora, pagando o preço e tornando-se, a partir daquele momento, credores da companhia., ${ }^{26}$

Nesse passo, como regra geral, a emissão é ato de competência privativa da assembleia geral. Como exceção, somente aplicáveis às companhias abertas, menciona-se a deliberação do conselho de administração de debêntures não conversíveis em ações, salvo vedação do estatuto; a emissão de debêntures conversíveis, no limite do capital autorizado; e a delegação da assembleia geral, fixadas suas características essenciais (arts. 59, §§ 1, 2 e 4, da $\operatorname{LSA})^{27}$.

Nota-se, assim, que a delegação da competência para deliberação sobre a emissão de debêntures ao conselho de administração só ocorre nas companhias abertas, sendo inexistente em companhias fechadas. A deliberação pela assembleia geral, ainda, deve obedecer a certos requisitos mínimos, constantes nos incisos do artigo 59 da LSA, que integrarão posteriormente a escritura de emissão, se resumindo às condições gerais da emissão, quais sejam a existência de garantia, conversibilidade e correção monetária, por exemplo.

É admitido pela LSA, ainda, a divisão de uma emissão em uma ou mais séries, que poderão ter valor nominal e direitos diferentes, à

\footnotetext{
${ }^{26}$ EIZIRK, Nelson. Emissão de Debêntures. Revista dos Tribunais. São Paulo: Thompson Reuters, 1995. vol. 721, p. 53.

27 “Art. 59. A deliberação sobre emissão de debêntures é da competência privativa da assembléiageral, que deverá fixar, observado o que a respeito dispuser o estatuto:

$[\ldots]$

VI - a época e as condições de vencimento, amortização ou resgate;

VII - a época e as condições do pagamento dos juros, da participação nos lucros e do prêmio de reembolso, se houver;

VIII - o modo de subscrição ou colocação, e o tipo das debêntures.

$\S 1^{\circ} \mathrm{Na}$ companhia aberta, o conselho de administração pode deliberar sobre a emissão de debêntures não conversíveis em ações, salvo disposição estatutária em contrário.

$\S 2^{\circ}$ O estatuto da companhia aberta poderá autorizar o conselho de administração a, dentro dos limites do capital autorizado, deliberar sobre a emissão de debêntures conversíveis em ações, especificando o limite do aumento de capital decorrente da conversão das debêntures, em valor do capital social ou em número de ações, e as espécies e classes das ações que poderão ser emitidas. $\S 4^{\circ}$ Nos casos não previstos nos $\S \S 1$ o e 20 , a assembleia geral pode delegar ao conselho de administração a deliberação sobre as condições de que tratam os incisos VI a VIII do caput e sobre a oportunidade da emissão."
} 
discricionariedade do emissor. Não obstante a divisão, as debêntures de uma mesma série deverão, necessariamente, ser iguais (ou fungíveis).

Todas as debêntures, independente da série, terão um valor nominal, sendo esse o valor inscrito no título, e deverá ser expresso em moeda corrente nacional. Matematicamente, o valor nominal de cada título será o valor total da emissão, divido pela quantidade de debêntures que a compõem. De toda forma, a emissão não deve, obrigatoriamente, fazer-se por valor nominal, sendo permitido a prática de ágio ou deságio, que serão fixados visto a conveniência e atratividade do título ${ }^{28}$.

Em regime anterior, restringia-se uma nova emissão de debêntures até a colocação de todas as debêntures de série anterior, ou o cancelamento do saldo. Inovou, nesse ponto, a Lei n 12.431 , de 24 de junho de 2011 ("Lei n 12.431/11") ao alterar o artigo 59 da LSA, removendo essa limitação.

Da mesma forma, vigorava sob a redação original da LSA, em seu artigo 60, a limitação da emissão de debêntures ao montante do capital social. Nesse ponto, comenta OTÁVIO YAZBEK:

\begin{abstract}
"O fato é que, já há muito, se reconhece que o capital social não dá uma verdadeira medida da capacidade de pagamento da companhia e que, a despeito das muitas formulações, tradicionalmente reiteradas na doutrina societária, que reiteram a função de garantia aos credores, são evidentes as suas limitações para tal. Indo além, é importante lembrar que as possibilidades de endividamento hoje são tão amplas, inclusive a partir do uso de novos instrumentos de mercado, que os limites formais estabelecidos para as debêntures representam muito pouco e servem muito mais para afastar os potenciais usuários desse instrumento do que para outra coisa" ${ }^{29}$.
\end{abstract}

Reconhecendo essa medida, a Lei n ${ }^{\circ} 12.431 / 11$ revogou o artigo 60 da LSA, de modo que, hoje, não se utiliza o parâmetro do capital social para limitar uma emissão de debêntures. Portanto, ao planejar uma emissão, pode

\footnotetext{
28 José Edwaldo Tavares Borba ainda faz a diferenciação entre preço de colocação e valor de emissão. A distinção se dá visto que o preço de colocação deverá refletir a soma dos direitos acumulados da data de emissão até a colocação, equivalendo ao valor de emissão mais o rendimento acumulado. (BORBA, José Edwaldo Tavares. Das Debêntures. Rio de Janeiro: Editora Renovar, 2005. p, 35.)

29 YAZBEK, Otávio. A Modernização do Regime das Debêntures e a criação de um Mercado de Dívida de Longo Prazo no Brasil. In: Direito Empresarial e Outros Estudos em Homenagem ao Professor José Alexandre Tavares Guerreiro. CASTRO, Rodrigo R Monteiro de et al. São Paulo: Quartier Latin, 2013, p. 583.
} 
uma sociedade fazer juízo, próprio, de seu nível de endividamento, e sua estrutura de capital, sem a limitação legal.

Uma vez deliberada a emissão pela assembleia geral ou conselho de administração de uma companhia, formaliza-se tal decisão na escritura de emissão, que para todos os efeitos é declaração unilateral da sociedade emissora, e conferirá todos os direitos dos debenturistas.

$\mathrm{Na}$ escritura deverão constar, no mínimo, as condições gerais referentes ao título, como o número de séries, vencimento e remuneração ${ }^{30}$. Esta deve, ainda, ser assinada por representantes da companhia, e pelo agente fiduciário (como interveniente anuente), em casos de colocação pública.

A LSA confere, nessa linha, a faculdade de aprovar cláusulas e condições padronizadas, que devem ser seguidas nas emissões de debêntures (art. 61, §3, LSA). Dessa forma, tal feito é disposto na Instrução CVM nº 404, de 13 de fevereiro de 2004, que denomina debêntures padronizadas como aqueles que sigam o formato previamente estabelecido pela autarquia, para negociação em mercados de bolsa e balcão.

Por fim, faz-se a diferenciação entre colocação pública e privada, visto o procedimento de registro diferenciado a ser adotado em cada caso. Em definição, colocação é o ato de oferecer debêntures à subscrição ${ }^{31}$, sendo feita a diferenciação entre pública e privada tendo em vista o ofertante, os destinatários da oferta e os meios utilizados para sua distribuição.

As colocações públicas, nos termos do artigo 19 da Lei nº 6.385/76, são aquelas destinadas ao público em geral, valendo-se de meios que buscam a legitimar esse alcance, como folhetos, prospectos, ou agentes intermediários como corretoras. Referidas colocações, à luz do princípio do full disclosure, que visa a permitir os investidores, no mercado, ter acesso a informações adequadas para fundamentação de suas decisões de investimento, precisam ser devidamente registradas na CVM.

\footnotetext{
30 “Art. 61. A companhia fará constar da escritura de emissão os direitos conferidos pelas debêntures, suas garantias e demais cláusulas ou condições."

${ }^{31}$ GUIMARÃES, Francisco José Pinheiro. Debêntures. In: LAMY FILHO, Alfredo e BULHÕES PEDREIRA, José Luiz (Coor.). Direito das Companhias. $2^{a}$ Edição. Rio de Janeiro: Editora Forense, 2017. p, 444.
} 
Nessa linha, a CVM, ao analisar a documentação de registro de uma emissão de debêntures, exerce poder vinculado, o que importa dizer a ausência de discricionariedade sob o deferimento do pedido de registro, fazendo juízo somente na medida de adequação da documentação, devendo se afastar do exame da qualidade dos títulos, oportunidade do emissor ou conveniência da oferta. NELSON EIZIRIK ensina, ainda, que a CVM indeferirá o pedido nos seguintes casos:

\begin{abstract}
"A CVM pode indeferir o pedido de registro da emissão pública apenas nas seguintes hipóteses: 1. caso a companhia não apresente as informações consideradas necessárias à correta avaliação, por parte dos investidores, sobre o mérito do empreendimento, as quais estão minuciosamente descritas nas normas administrativas baixadas pela CVM, ou caso a companhia apresente tais informações de maneira incompleta ou insatisfatória (Instrução CVM n. 13/80, Anexo I); 2. caso o estatuto social da companhia contenha dispositivos ilegais, ou os atos societários que precederam a emissão sejam irregulares ou viciados. Em tais hipóteses, o deferimento do pedido do registro é condicionado ao atendimento das exigências formuladas pela CVM, inclusive quanto às necessárias alterações no Estatuto Social da companhia para adaptá-lo à lei (Instrução CVM n. 13/80, art. 13, b)." ${ }^{32}$
\end{abstract}

Em todos casos, independente da classificação da colocação como pública ou privada, são mandatórios os requisitos constantes no artigo 62 da LSA. Assim, faz-se necessário o arquivamento da ata da assembleia geral ou da reunião do conselho de administração que deliberou sobre a emissão e a escritura de emissão no registro do comércio, além da constituição das garantias, se for o caso $^{33}$.

\title{
I.3.2 Espécies de Debêntures
}

Expostos os fundamentos de emissão de debêntures no direito brasileiro vigente, torna-se, nesse momento, às espécies de garantias dos debenturistas. Dessa forma, a LSA denominou espécies, as garantias das debêntures.

Sob essa ótica, o artigo 58 da $\mathrm{LSA}^{34}$ estabelece quatro formas de garantias, as quais podem ser constituídas em benefício do debenturista.

\footnotetext{
${ }^{32}$ EIZIRK, Nelson. Emissão de Debêntures. Revista dos Tribunais. São Paulo: Thompson Reuters, 1995, p, 55.

${ }^{33}$ GUIMARÃES, Francisco José Pinheiro. Op. Cit., p, 448.

34، Art. 58. A debênture poderá, conforme dispuser a escritura de emissão, ter garantia real ou garantia flutuante, não gozar de preferência ou ser subordinada aos demais credores da companhia.
} 
Nessa dinâmica, são elas: reais, flutuantes, quirografárias ou subordinadas. Como observa FRANCISCO JOSÉ PINHEIRO GUIMARÃES, mesmo constituídas garantias em nome dos credores, não são essas afirmativas quanto ao sucesso do empreendimento, mas apenas auxiliam na redução destes riscos:

"Por outro lado, as garantias prestadas em favor dos debenturistas têm por objetivo vincular determinado bem ao pagamento das debêntures. Funcionam como uma fonte alternativa de pagamento, a ser utilizado pelos debenturistas em caso de não pagamento dos valores a eles devidos. As garantias assumem, nesse contexto, natureza curativa. Servem para sanar eventual inadimplência da companhia emissora, porém não têm o condão de impedir a deterioração das condições econômicas e financeiras da companhia emissora, tampouco prevenir o inadimplemento" 35 .

As garantias reais, dessa forma, são aquelas que vinculam determinados bens, que podem ser da própria emitente ou de terceiro, ao pagamento da dívida. A disciplina das garantias reais é dada pela lógica do Direito Civil, sendo somente apropriada por instrumento societário.

Nesse sentido, podem ser constituídos hipoteca, penhor, anticrese, ou, ainda, alienação fiduciária. CAIO MARIO DA SILVA PEREIRA ${ }^{36}$, assim, estabelece efeitos comuns às garantias reais.

O primeiro é o direito de preleção ou preferência que o credor garantido goza sobre o bem dado em garantia, o que importa dizer é que paga-se o credor prioritariamente sobre o valor liquidado do bem, independente de garantia geral, no montante de seu crédito. Em seguida, fala-se no direito de

\footnotetext{
$\S 1^{\circ}$ A garantia flutuante assegura à debênture privilégio geral sobre o ativo da companhia, mas não impede a negociação dos bens que compõem esse ativo.

$\S 2^{\circ}$ As garantias poderão ser constituídas cumulativamente.

$\S 3^{\circ}$ As debêntures com garantia flutuante de nova emissão são preferidas pelas de emissão ou emissões anteriores, e a prioridade se estabelece pela data da inscrição da escritura de emissão; mas dentro da mesma emissão, as séries concorrem em igualdade.

$\S 4^{\circ}$ A debênture que não gozar de garantia poderá conter cláusula de subordinação aos credores quirografários, preferindo apenas aos acionistas no ativo remanescente, se houver, em caso de liquidação da companhia.

$\S 5^{\circ}$ A obrigação de não alienar ou onerar bem imóvel ou outro bem sujeito a registro de propriedade, assumida pela companhia na escritura de emissão, é oponível a terceiros, desde que averbada no competente registro.

$\S 6^{\circ}$ As debêntures emitidas por companhia integrante de grupo de sociedades (artigo 265) poderão ter garantia flutuante do ativo de 2 (duas) ou mais sociedades do grupo."

${ }^{35}$ GUIMARÃES, Francisco José Pinheiro. Op. Cit.. p, 440.

${ }^{36}$ PEREIRA, Caio Mário da Silva. Instituições de Direito Civil - Volume IV. $25^{\mathrm{a}}$ Edição. Rio de Janeiro: Forense, 2017. p, 288.
} 
sequela, sendo esse o direito real de perseguir a coisa, independente de sua posse, ou poder com quem ela se encontre.

No demais, fala-se em direito de excussão do bem, dito assim a capacidade de leva-lo à venda em pregão, pela via judicial, uma vez vencida e não paga a obrigação. E, por último, dispõe o credor com garantia real, da indivisibilidade de sua garantia, o que importa dizer que a garantia sobrevive integralmente mesmo paga parcialmente a dívida, ou, em caso de garantia superior à dívida, eximir a coisa de ônus.

A garantia real pode ser constituída, ainda, sob bens futuros, a qual a companhia se compromete a constituir posteriormente à emissão. Em todo caso, a garantia real, além de constar na escritura, deve ser constituída por meio de registro, conforme o caso, de modo que possa opô-la contra terceiros. Nota-se, ainda, que é possível constituir garantia real em nome de só uma série de mesma emissão.

De outro modo, pode a debênture contar com garantia flutuante. Essa modalidade de garantia corresponde ao privilégio geral sob os bens livres e desembaraçados de ônus da companhia emissora, em caso de concurso de credores. Considera-se a garantia flutuante, pois não impede mutações no estado patrimonial da emissora, enquanto não for aberto concurso de credores, sendo essa livre para criar gravames e onerar seus bens, no decurso normal de suas atividades.

Ponto interessante da garantia flutuante é a permissão de constituição de garantia em nome de mais de uma sociedade do mesmo grupo econômico. Nesse caso, o credor garantido teria prioridade sobre os ativos de companhia componente do grupo econômico, até o limite da garantia constituída.

Em se falando da garantia flutuante, deve-se destacar que existe uma desvantagem relativa ao debenturista: a companhia pode alienar bens até a abertura do concurso de credores, o que torna, em certa medida, a garantia apenas nominal. De todo modo, é permitido que conste cláusula na escritura de emissão restringindo a liberdade da emissora de dispor do seu ativo. Nessa lógica, orienta LUIZ GASTÃO PAES DE BARROS LEÃES: 
"Com efeito, a chamada "garantia flutuante" das debêntures aqui ou alhures, não vincula, de maneira nenhuma, os bens que compõem o ativo à garantia que o titular ofereceu. Como julgo ter demonstrado à saciedade, com apoio da doutrina e na jurisprudência alienígenas, a garantia flutuante não estabelece um gravame direto sobre os bens do ativo, visto que não desfruta da natureza de um direito real de garantia. Nessas condições, ao serem alienados, esses bens não transportam consigo quaisquer ônus, já que não os tem, nem a garantia flutuante dispõe de direito de sequela". ${ }^{37}$

Uma vez disposta na escritura de emissão, a garantia flutuante abrange todas as séries de uma mesma emissão. Contudo, conforme expresso no artigo $59, \S 3^{\circ}$, da LSA, se obedece à regra de preferência entre emissões da companhia, sendo que emissões anteriores preferem novas emissões.

A lei fala, ainda, em debêntures quirografárias, ou sem garantia. Essas, concorrem em igualdade de condiçõos com os demais credores da sociedade, sem que haja, contudo, preferência sobre o patrimônio livre e desembaraçado da companhia, ou bens vinculados ao pagamento.

Visto que a garantia quirografária, à primeira leitura, expõe o credor ao risco da administração da companhia, permite-se, contratualmente, sua suplementação pela restrição de oneração ou constituição de garantias, no que tange o patrimônio geral da emissora. Nesse caso, preserva-se o credor quirografário contra o consumo do ativo por credor com preferência, mas evidentemente, não alcança garantias anteriormente constituídas.

Por último, consagra-se a debênture subordinada. Nesse caso, o debenturista, ocorrendo a liquidação da companhia, é preferido por todas as dívidas não subordinadas da companhia, havendo preferência somente sobre os acionistas da emissora.

A subordinação opera, assim, apenas em caso de liquidação da sociedade. Durante sua vida útil, as debêntures subordinadas têm funcionamento normal, conforme os termos da escritura de emissão.

Nada impede, sob a luz da LSA, que sejam cumuladas garantias, desde que logicamente possível. Pode ocorrer, por exemplo, caso em que o credor conte com garantia real e flutuante, em seu favor.

\footnotetext{
${ }^{37}$ LEÃES, Luiz Gastão Paes de Barros. Estudos e Pareceres sobre Sociedades Anônimas. São Paulo: Editora Revista dos Tribunais, 1989, p, 91.
} 
Ainda que não constante na LSA, permite-se a constituição de garantias pessoais aos debenturistas. Essas, serão disciplinadas conforme o Código Civil $^{38}$.

\section{I.3.3 Agente Fiduciário}

Insere-se nessa dinâmica, ainda, o agente fiduciário. Conforme narra TAVARES BORBA, o instituto tem inspiração no direito anglo-saxão, sob a forma do trust. Nesse, o trustee se obriga a exercer direito em prol de outro, o beneficiário (settlor). Dessa relação, cria-se uma divisão entre interesse formal e material, a qual se vale nosso direito vigente. Expõe o autor:

"O agente fiduciário deve ser entendido como uma figura inspirada no trust, mas sem a conotação de transferência de propriedade, tanto que os títulos permanecem no domínio dos debenturistas; detém ele, no entanto, uma legitimação extraordinária, que decorre da lei, para adotar, judicial e extrajudicialmente, como se fora o proprietário, e portanto em nome próprio, todas as providências necessárias à plena realização dos créditos correspondentes aos títulos" ${ }^{\prime 39}$.

Isto posto, a LSA, em seu artigo 68, estipula ao agente fiduciário a capacidade de agir em nome da comunhão de interesses dos debenturistas, zelando e protegendo seus direitos. Nota-se, assim, que este é legalmente representante dos debenturistas, sendo seus poderes derivados da lei e da escritura de emissão.

Conforme se depreende da conceituação das debêntures como título de massa, torna-se impraticável o exercício individual dos direitos de cada debenturista. É dessa dificuldade prática que se fundamenta a existência de um agente fiduciário.

Nesse sentido, podem ser agentes fiduciários, no Brasil, instituições financeiras autorizadas pelo Banco Central a realizar a atividade de administração ou custódia de bens de terceiros, e pessoas naturais que se enquadrem na definição do artigo 147 da LSA. Uma vez nomeados, os

\footnotetext{
${ }^{38}$ BORBA, José Edwaldo Tavares. Das Debêntures. Rio de Janeiro: Editora Renovar, 2005. p, 80.

${ }^{39}$ BORBA, José Edwaldo Tavares. Op. Cit., p, 155.
} 
agentes adquirem um dever de fidúcia para com os debenturistas, devendo conduzir o interesse da comunhão como o faria com seus próprios bens.

Dentre suas atribuições, ressalta-se a função de notificar os debenturistas em caso de inadimplência da companhia, declarando o vencimento antecipado do título, caso cabível. Pode o agente, ainda, executar eventual garantia, em benefício dos debenturistas, valendo-se das ações adequadas para perseguição de tal fim.

Fazendo-se necessário a propositura de ação judicial para proteção dos interesses da comunhão, o agente fiduciário tem a capacidade de representação processual dos debenturistas. Nesses termos, conforme se reporta a doutrina, a propositura individual de ações pelos debenturistas só tem lugar uma vez dissolvida a comunhão ${ }^{40}$.

Anteriormente à promulgação da Lei $\mathrm{n}^{\circ} 12.431 / 11$, constava na LSA vedação à cumulação da função de agente fiduciário, pela mesma instituição ou pessoa natural, em se tratando de emissões da mesma companhia. Da mesma forma, a Instrução CVM n ${ }^{\circ} 28$, de 23 de novembro de 1983 ("ICVM 28/83), ao regular a matéria, consolidava posicionamento mais extenso, restringindo, também, para "sociedade coligada, controlada, controladora da emissora ou integrante do mesmo grupo".

Visto as reformas propostas pela lei em referência, a LSA, hoje, adaptando-se às condições de mercado, que praticava diversas emissões por mesmos emissores, e buscava maior fungibilidade dos títulos, prevê a possibilidade de autorização pela CVM da cumulação da função de agente fiduciário. Nessa linha, a ICVM 28/83 foi posteriormente revogada pela ICVM n $^{\circ} 583$, de 20 de dezembro de 2016, não vigorando tal vedação.

\footnotetext{
${ }^{40}$ Nesse sentido dispõe Francisco José Pinheiro Guimarães: "No que se refere à legitimidade do debenturista para acionar, individualmente, a companhia emissora das debêntures, vale lembrar que a questão já se encontra pacificada na doutrina. As ações individuais dos debenturistas contra companhia emissora somente serão permitidas se a comunhão dos debenturistas for desfeita por decisão da unanimidade dos debenturistas reunidos em assembleia que exima o agente fiduciário dos seus deveres e atribuições legais, observado que nas hipóteses de representação em processo de falência, recuperação judicial ou extrajudicial, intervenção ou liquidação extrajudicial da companhia emissora, a decisão por maioria será suficiente" GUIMARÃES, Francisco José Pinheiro. Debêntures. In: LAMY FILHO, Alfredo e BULHÕES PEDREIRA, José Luiz (Coor.). Direito das Companhias. $2^{\text {a }}$ Edição. Rio de Janeiro: Editora Forense, 2017. P, 456.
} 
Pelo exposto, denota-se a importância do agente fiduciário, figura representativa dos interesses da comunhão dos debenturistas. Além das funções já descritas, o agente deverá reportar-se via relatório anual, que consolidará os fatos relevantes ocorridos durante o exercício.

\section{I.3.4 Vencimento, amortização e resgate}

Exceto pela debênture perpétua, cujo vencimento se dará em hipótese de inadimplemento, o vencimento é requisito essencial da debênture, devendo constar na escritura de emissão. É somente nessa data que o título passa a ser exigível, o que permite, entre outras coisas, a execução da companhia, por parte do debenturista. Faculta-se à companhia emissora, ainda, criar fundos de amortização e estipular resgate total ou parcial, de cada série (art. 55, $\mathrm{LSA})^{41}$.

Amortização é o ato de pagar parcialmente o valor da dívida. Dito de outra forma, é a diminuição do valor do principal, antes do vencimento do título. Em termos práticos, a amortização tem grande relevância para o pagamento de dívidas, uma vez que reduz o montante - principal -, sobre o qual incidirão juros. Dessa forma, considerando o fluxo de caixa do passivo da companhia, com a amortização, a emissora pagará valor menor de juros, visto que a base de cálculo será menor a partir de um dado período.

\footnotetext{
41 “Art. 55. A época do vencimento da debênture deverá constar da escritura de emissão e do certificado, podendo a companhia estipular amortizações parciais de cada série, criar fundos de amortização e reservar-se o direito de resgate antecipado, parcial ou total, dos títulos da mesma série. § 1o A amortização de debêntures da mesma série deve ser feita mediante rateio.

$\S 20$ O resgate parcial de debêntures da mesma série deve ser feito:

I - mediante sorteio; ou

II - se as debêntures estiverem cotadas por preço inferior ao valor nominal, por compra no mercado organizado de valores mobiliários, observadas as regras expedidas pela Comissão de Valores Mobiliários.

§ 3o É facultado à companhia adquirir debêntures de sua emissão:

I - por valor igual ou inferior ao nominal, devendo o fato constar do relatório da administração e das demonstrações financeiras; ou

II - por valor superior ao nominal, desde que observe as regras expedidas pela Comissão de Valores Mobiliários.

§ 4o A companhia poderá emitir debêntures cujo vencimento somente ocorra nos casos de inadimplência da obrigação de pagar juros e dissolução da companhia, ou de outras condições previstas no título."
} 
Pode, assim, a companhia emissora amortizar periodicamente as debêntures ou em uma única vez ${ }^{42}$. De outra forma, é possível a estipulação na escritura de emissão das condições específicas segundos as quais a amortização deverá ocorrer. Em caso de estabelecimento de fundo de amortização, o qual deve constar na escritura de debêntures, a companhia obriga-se a depositar recursos, usualmente custodiados por instituição financeira, e que deverão ser utilizados na amortização da dívida.

Nessa esteira, a LSA dispõe que a amortização de debêntures de uma mesma série se dará mediante rateio. Em regime anterior, consagrava-se a possibilidade de sorteio, o que, contudo, foi modificado pela Lei $\mathrm{n}^{\mathrm{o}}$ 12.431/11, o que parece ser uma opção mais racional, na dinâmica da amortização, uma vez que a amortização é abrangente e se estende a todos os títulos de uma mesma série, enquanto o sorteio, por ser aleatório, e somente aplicável às debêntures sorteadas, prejudicaria o tratamento equitativo entre os debenturistas.

Difere-se da amortização, dessa forma, o resgate. $O$ resgate consiste no pagamento antecipado do valor nominal do título, o que implica, também, em converter a zero a base de cálculo dos juros, e consequentemente removêlo do mercado. OTÁVIO YAZBEK consagra o resgate como:

"Já o resgate é a operação pela qual a companhia efetua o pagamento do valor da debênture, antes do vencimento, retirando-a de circulação. Pela sua própria natureza, e ao contrário do que acontece com a amortização, o resgate pode abranger todas as debêntures de uma série (no caso do resgate total) ou apenas algumas (o chamado resgate parcial $)^{43}$.

Ao contrário do que acontece com a amortização, a LSA autoriza o resgate de debêntures de uma mesma série mediante sorteio, ou, em caso de

\footnotetext{
${ }^{42}$ Existem sistemas próprios de amortização de dívida. No Brasil, utiliza-se o método SAC - Sistema de Amortização Constantes e o Sistema Price, em ambos os casos, a amortização é feita a cada pagamento. O sistema americano, de outra forma, pressupõe o pagamento de juros constantes e amortização total na data de vencimento. (ROSS, Stephen A; Fundamentos da Administração Financeira. $9^{a}$ Edição. Porto Alegre: AMGH, 2013. p, 173).

43 YAZBEK, Otávio. A Modernização do Regime das Debêntures e a criação de um Mercado de Dívida de Longo Prazo no Brasil. In: Direito Empresarial e Outros Estudos em Homenagem ao Professor José Alexandre Tavares Guerreiro. CASTRO, Rodrigo R Monteiro de et al. São Paulo: Quartier Latin, 2013, p, 575.
} 
estarem cotadas por valor inferior ao nominal, por compra no mercado organizado. Permite-se o sorteio, nesse caso, de forma a evitar arbitrariedades, considerando que o resgate pode abranger, ou não, todas as debêntures de uma mesma série.

Pode-se prever, ainda, na escritura de emissão, eventual prêmio de resgate, o qual terá direito o debenturista resgatado. Como se refere à literatura financeira ${ }^{44}$, o resgate antecipado de um título expõe o investidor a determinados riscos de mercado. Nessa lógica, em casos de autorização de resgate, a LSA autoriza a prática do prêmio, de modo a estimular o investimento, mesmo nestas condições. Conceitua-se, assim, o prêmio de reembolso como a diferença entre o valor nominal do título e a quantia paga no resgate.

Por fim, em fenômeno parecido, a LSA dispõe dos procedimentos de recompra de títulos de sua própria emissão. Nessa lógica, é permitido que a recompra seja feita por valor igual ou inferior ao valor nominal, ou superior, desde que atendidas às exigências da $\mathrm{CVM}^{45}$.

\section{I.4 O incentivo fiscal da Lei no $12.431 / 11$}

A Lei $\mathrm{n}^{\circ}$ 12.431/11, originariamente publicada como MP n ${ }^{\circ} 507 / 10$, além das modificações já mencionadas à LSA, em movimento para estimular o financiamento de modalidades determinadas de projetos, trouxe uma nova dinâmica ao mercado de dívida corporativa brasileiro, qual seja, o incentivo

\footnotetext{
${ }^{44}$ Sobre o tema, expõe FABOZZI: "First, callable bonds expose bondholders to reinvestment risk, since an issuer will call a bond when the yield on bonds in the market is lower than the issue's coupon rate. [...]. Second, as we explain later in this chapter, the price appreciation potential for a callable bond in a declining interest-rate environment is limited. This is because the market will increasingly expect the bond to be redeemed at the call price as interest rates fall. This phenomenon for a callable bond is referred to as price compensation.". FABOZZI, Frank J. Bond Markets, Analysis and Strategies. Prentice-Hall, Inc. 3rd Edition, New Jersey. 1996. p, 327.

${ }^{45}$ Recentemente, a CVM abriu edital de Audiência Pública para discutir o tema (Edital de Audiência Pública SDM no 06/19).
} 
fiscal. Pratica-se, nesse sentido, estímulo à emissão de debêntures, nos termos propostos pela $1 \mathrm{ei}^{46}$.

O referido incentivo, nesse quadro, somente será aplicado em se tratando de debêntures emitidas por Sociedades de Propósito Específico (SPE), ou por sociedades controladoras das mesmas, cujo objetivo seja o investimento em áreas específicas e julgadas pertinentes pelo legislador, classificadas como infraestrutura e investimento, sobretudo nas áreas de pesquisa, desenvolvimento e inovação. A concessão do benefício depende, ainda, da autorização do órgão administrativo competente, conforme o caso.

Diz-se incentivada visto que o investidor goza, de fato, de alíquota mais benéfica no imposto de renda, nesses casos. Assim, a alíquota para investidor pessoa física passou a zero, ao passo que para pessoas jurídicas, 15\%. O cotista de fundo que tenha $85 \%$, no mínimo, de sua carteira aplicada nestes títulos, passa, também, a gozar da referida isenção. Assim, orientam GABRIEL FIUZA DE BRAGANÇA et al.:

"A Lei $\mathrm{n}^{\circ}$ 12.431/2011 criou as debêntures de infraestrutura ou debêntures incentivadas, que correspondem a variações das debêntures convencionais, com o diferencial de possuir alíquotas de imposto de renda (IR) reduzidas. Além disso, contam com benefícios fiscais distintos para residente no exterior, residente doméstico, pessoa física e jurídica. Em relação ao primeiro, o IR é zero. Quanto ao segundo, as debêntures têm alíquota de IR de $15 \%$ quando adquiridas por pessoa jurídica e nula no caso de pessoa física." 47

\footnotetext{
46 “'Art. $2^{\circ}$ No caso de debêntures emitidas por sociedade de propósito específico, constituída sob a forma de sociedade por ações, dos certificados de recebíveis imobiliários e de cotas de emissão de fundo de investimento em direitos creditórios, constituídos sob a forma de condomínio fechado, relacionados à captação de recursos com vistas em implementar projetos de investimento na área de infraestrutura, ou de produção econômica intensiva em pesquisa, desenvolvimento e inovação, considerados como prioritários na forma regulamentada pelo Poder Executivo federal, os rendimentos auferidos por pessoas físicas ou jurídicas residentes ou domiciliadas no País sujeitamse à incidência do imposto sobre a renda, exclusivamente na fonte, às seguintes alíquotas:

I - $0 \%$ (zero por cento), quando auferidos por pessoa física; e

II - $15 \%$ (quinze por cento), quando auferidos por pessoa jurídica tributada com base no lucro real, presumido ou arbitrado, pessoa jurídica isenta ou optante pelo Regime Especial Unificado de Arrecadação de Tributos e Contribuições devidos pelas Microempresas e Empresas de Pequeno Porte (Simples Nacional)".

${ }^{47}$ BRAGANÇA, Gabriel G. Fiuza. Evolução Recente do Mercado de Debêntures no Brasil: As Debêntures Incentivadas. Instituto de Pesquisa Econômica Aplicada. Rio de Janeiro: IPEA, 2015. $\mathrm{p}, 7$.
} 
Prosseguiu, ainda, a reforma legal, modernizando algumas características do mercado de dívida anteriormente vigente. Dessa forma, destacam ERNANI TEIXEIRA TORRES FILHO E LUIZ MACAHYBA:

\begin{abstract}
"Além das medidas relacionadas aos incentivos às emissões de dívidas corporativas de longo prazo para investimentos, a Lei 12.431 também eliminou alguns dos obstáculos existentes ao desenvolvimento do mercado secundário de títulos de dívida. $\mathrm{O}$ artigo $5^{\circ}$ acabou com uma grave distorção existente na legislação do Imposto Renda incidente no pagamento de cupons. Até então, se o investidor adquirisse no mercado secundário um título que pagasse rendimentos periódicos seria penalizado pela bitributação do rendimento, já que o imposto era recolhido pro rata tempore no momento em que o papel trocava de proprietário e novamente, pelo seu valor integral, na data do pagamento do cupom, em geral realizado semestralmente pelo emissor." 48
\end{abstract}

Não é, todavia, sem contrapartida o benefício fiscal. A Lei no 12.431/11, em seu artigo $1, \S 1^{\circ}$, estabelece alguns requisitos as quais emissões dessa natureza, e que pretendam o referido benefício, devam seguir.

Nesse sentido, estabelece-se o prazo médio ponderado de quatro anos, a necessidade de remuneração pré-fixada ou vinculada a índice de preço ou taxa referencial de juros, e pagamento de rendimentos em prazo não superior a 180 dias, por exemplo. Quanto à emissão, deve ser ela realizada por esforços restritos (ICVM 476/09) e negociada em mercados regulados de valores mobiliários.

\footnotetext{
48 TORRES FILHO, Ernani Teixeira; MACAHYBA, Luiz. O Elo Perdido. O Mercado de Títulos de Dívida Corporativa no Brasil: Avaliação e Propostas. São Paulo: Instituto de Estudos para o Desenvolvimento Industrial - IEDI/Instituto Talento Brasil, 2012. p, 60.
} 


\section{CAPÍTULO II - MICROESTRUTURA DO MERCADO DE DEBÊNTURES}

Define-se microestrutura de mercado como o estudo das condições em que as negociações ocorrem em determinados mercados, por determinados períodos de tempo ${ }^{49}$. Nessa linha, sob tal carácter, expande-se uma infinidade de tradições teóricas.

Quando se fala em microestrutura do mercado de debêntures, assim, se supõe uma série de questões, que envolvem, entre outras coisas, a consideração do ambiente (Brasil) em que tais operações tomam lugar. Ainda, diante de condições de racionalidade dos agentes econômicos, que deve ser um pressuposto para o embasamento do trabalho, prevalece-se um conjunto de escolhas, dado uma série de possibilidades, com o intuito de maximização de seus resultados. Dessa massa estatística de decisões, desenvolve-se o estudo da microestrutura de mercado - no presente trabalho com o enfoque sobre suas repercussões jurídicas deste quadro.

Nesse sentido, inicialmente, conceitua-se o mercado de debêntures, em escala global (como bonds, em geral), salvo algumas exceções, como essencialmente de balcão ${ }^{50}$. Diferem-se, assim, dos mercados de ação, predominantemente de bolsa.

No Brasil, em consonância com o que se descreve, o mercado é majoritariamente de balcão, o qual se desdobra por meio do sistema da CETIP. Em oposição, mesmo que em montante inferior, existem debêntures negociadas em bolsa, as quais se valem do sistema Bovespafix (sistema da Bovespa de renda fixa $)^{51}$.

\footnotetext{
49 "It is assumed that a collection of market agents can be treated as a statistical ensemble. Their market activities are depicted as the stochastic generation of market orders according to a Poisson process. The objective is to effectively describe the 'temporal microstructure', or moment-tomoment trading activities in asset markets.' GARMAN, Mark.B. Market Microstructure. Journal of Financial Economics 3. Columbia, 1976, p. 257.

50 BIAIS, Bruno; Richard Green. The Microstructure of the Bond Market in the 20th Century. Review of Economic Dynamics. Vol. 33. EUA, 2019, p. 3.

${ }^{51}$ ANBIMA. Non-Resident Investors Guide. São Paulo: ANBIMA, 2018. p. 13.
} 
Distribuições públicas podem ser realizadas por meio da Instrução CVM n 400 , de 29 de dezembro de 2003 ("ICVM 400"), ou pela Instrução CVM $\mathrm{n}^{\circ}$ 476, de 16 de janeiro de 2009 ("ICVM 476"). Diferenciando-se em larga medida, visto que a primeira é dirigida ao público em geral, e precede registro na CVM, enquanto a segunda é feita a um número restrito de investidores profissionais, e somente será comunicada à CVM após seu início ${ }^{52}$.

Dessa forma, neste Capítulo, consideram-se as condições históricas, regulatórias e de mercado, referentes às debêntures do Brasil. No item II.1, será demonstrada a evolução do mercado, considerando a trajetória do período de alta inflação até a prática nos dias de hoje. Em seguida (II.2), narra-se o papel dos intermediários (underwriter), na distribuição dos valores mobiliários. Ainda, no item II.3 se demonstra como se dá a coexistência com títulos públicos, historicamente. E, por fim, tece-se alguns comentários sobre o papel dos derivativos na mitigação do risco de crédito.

\section{II.1. Evolução do Mercado de Debêntures}

Como ponto de partida, a literatura financeira analisa como as condições macroeconômicas, ou a incerteza acerca delas, afetam o preço e negociabilidade de ativos. Nessa linha, a teoria da liquidez pressupõe a existência de uma relação entre liquidez e incerteza, tese adotada em alguns estudos sobre mercado de dívida ${ }^{53}$.

Assim, tendo em vista o mercado brasileiro da década de 90, CHRISTOPHER W. ANDERSON analisou as características contratuais de 50 debêntures, emitidas entre 1989 e 1993, de modo a prever como riscos institucionais são mitigados por previsões contratuais. O arcabouço teórico utilizado pelo autor, dessa forma, advém de estudos que demonstram uma

\footnotetext{
52 “Art. $7^{\circ}$-A O início da oferta pública distribuída com esforços restritos deverá ser informado pelo intermediário líder à CVM, no prazo de 5 (cinco) dias úteis, contado da primeira procura a potenciais investidores."

53 PAULA, Luiz Fernando de; FARIA JR, João Adelino de. Mercado de Títulos de Dívida Corporativa Privada no Brasil: Aspectos estruturais e evolução recente. Revista de Economia Contemporânea. Rio de Janeiro: 2012, p. 107-137.
} 
relação positiva entre o desenho de cláusulas contratuais e conflitos corporativos. Dessa forma, busca-se mensurar as fontes de risco previstas nas cláusulas de debêntures, de modo a traçar uma relação com fatores institucionais brasileiros.

Dito isso, o autor delineia que o ambiente brasileiro teria potencial inibidor às relações comerciais, afetando a forma de negociação das debêntures na época. Assim estipula CHRISTOPHER W. ANDERSON:

"The environment in Brazil appears inimical to financial contracting. Table 2 reports that various indicators of country risk consistently rate Brazil as a high or moderate risk. While these ratings reflect various economic and institutional factors, four characteristics of the Brazilian economy are particularly relevant to financial contracting: high inflation, volatile real-sector activity, weak institutions, and an interventionist state. ${ }^{54}$.

Dessa forma, é descrito um cenário de volatilidade inflacionária relacionada à atividade econômica no $\mathrm{Brasil}^{55}$, a qual seria prejudicial ao estabelecimento de relações comerciais de longo prazo. Em seguida, o autor consagra que o ambiente institucional não privilegiaria suficientemente os direitos de propriedade, o que, somado à existência do que ele consagra como um estado intervencionista, transmitiria insegurança ao mercado ${ }^{56}$.

Em efeitos práticos, argumenta-se que os custos de contratação no Brasil seriam relativamente altos, em comparação com o cenário externo, o que reflete, dentre outras coisas, na existência de prêmio na remuneração das debêntures, transmitindo o risco de inflação para a companhia emissora. Da mesma forma, nota-se um padrão de cláusulas de recontratação ${ }^{57}$ que dariam

\footnotetext{
54 ANDERSON, Christopher W. Financial contracting under extreme uncertainty: an analysis of Brazilian corporate debentures. Journal of Financial Economics 51. Columbia: 1997. P, 49.

${ }^{55} \mathrm{O}$ autor converte o índice da BOVESPA, em dólar, de modo a compará-lo com o S\&P 500. Chega a uma conclusão, assim, que o desvio padrão do índice BOVESPA seria de 25,3\%, significativamente mais elevado que os 4,5\% do S\&P 500.

56 "Brazil's institutions are far from primitive, but they appear insufficiently developed to substantially assist parties to financial contracts. First, Brazil has a civil-law legal tradition, characterized by La Porta et al. (1997) as an impediment to external financing in general. The Brazilian legal system, in particular, does not employ the principle of stare decisis and the judiciary is regarded as inefficient and sometimes even corrupt (D’Almeida Pires Filho, 1991). Second, the quality of disclosure by Brazilian firms is perceived to be low." ANDERSON, Christopher W. Financial contracting under extreme uncertainty: an analysis of Brazilian corporate debentures. Journal of Financial Economics 51. Columbia: 1997. P, 53-54.

57 “As debêntures no mercado brasileiro geralmente incluem cláusulas de recontratação. Essas cláusulas oferecem custo menor de transação e possibilidade de tanto o emitente quanto os
} 
ao debenturista o direito de venda, em casos de desacordo acerca da revisão de determinados termos, além de provisões de resgate e vencimento antecipado, permitindo a redução de custos informacionais, uma vez que são renovadas para adaptar-se às novas percepções de risco institucionais incerto na época.

De maneira semelhante, o autor observa a frequência em que se estipula cláusula limitativa de distribuição de dividendos aos acionistas da emissora, restringindo-os, por vezes, à exigência mínima legal. Ainda, fazia-se constante a restrição à política de investimentos da emissora, modelando como a companhia poderia dispor de seu ativo.

Após a estabilização econômica brasileira, ANTÔNIO LUÍS LIMA FILGUEIRA e RICARDO PEREIRA CÂMARA LEAL, revisaram o estudo supracitado $^{58}$, tendo como base uma amostragem de debêntures emitidas entre 1994 e 1997, registradas na CVM e no Sistema Nacional de Debêntures (SND). Os autores notam, assim, visto o programa de desindexação econômica, após a implementação do Plano Real, uma repercussão na remuneração das debêntures. Nessa lógica, ressalta-se a Decisão-Conjunta BACEN/CVM n ${ }^{\circ}$ 3, de 7 de fevereiro de 1996, a qual limitou a utilização da cláusula de atualização monetária à períodos superiores a um ano. Ainda, vale observar que o normativo restringiu a utilização de indexação à inflação, o que teve como impacto o aumento do uso de juros remuneratórios compostos por uma parcela fixa e uma flutuante.

Como padrões gerais, nesse sentido, os autores narram a diminuição da prática de cláusulas em que se estipule prêmio de remuneração das debêntures, e diminuição das previsões de vencimento antecipado. Ponto interessante, ainda, é o aumento da utilização de cláusulas restritivas da

\footnotetext{
debenturistas renegociarem os termos do contrato para refletir as mudanças de mercado e as condições de crédito do emitente. Além disso, as opções de compra e de venda estão geralmente disponíveis nas escrituras de emissão de debêntures". SAITO, Richard et al. Governança Corporativa Embutida nas Escrituras de Debêntures Emitidas no Brasil. Revista de Administração da USP. São Paulo: RAUSP, 2008. p, 282.

58 FILGUEIRA, Antônio Luís Lima; LEAL, Ricardo Pereira Câmara. Cláusulas de Escrituras de Debêntures Brasileiras após a Estabilização Econômica. Instituto COPPEAD de Administração, UFRJ. Rio de Janeiro: COPPEAD, 2000. p, 1-15.
} 
política de investimento e financiamento das companhias emissoras, o que, à primeira vista, parece um contra senso visto o movimento mais liberal do mercado e suposta estabilização econômica. Em realidade, contudo, demonstra-se que o público investidor, no período, ainda percebia riscos institucionais nos títulos privados.

Ainda, em amostra composta por debêntures emitidas entre 1998 e 2005, RICHARD SAITO et al. utilizam a mesma metodologia dos estudos anteriores, com o enfoque no período da virada do século. Nessa linha, os autores argumentam que após a implementação do Plano Real, o mercado de debêntures expandiu-se consideravelmente. Atribuem a esse fato fundamentos de ordem estrutural - fortalecimento de órgãos reguladores, da estrutura legal e estabilidade da economia -, e de mercado, referente à demanda por financiamento e de títulos de renda fixa por investidores.

Nota-se, no estudo, que o mercado secundário apresentava baixíssima liquidez, o que restringia significativamente a negociação dos títulos. Assim, os debenturistas que subscreviam os títulos eram compelidos a segurá-los até o vencimento.

Quanto aos pontos mencionados nos estudos anteriores, cabe observar que RICHARD SAITO et al. identificaram um padrão de aumento de emissões sem indexação à inflação, o que pode indicar uma melhora na percepção, por parte do público investidor, do risco inflacionário ${ }^{59}$. Ainda, é mencionada diminuição na frequência de cláusulas de recontratação, que foi de 66\% no período entre 1989 a 1994, para somente 7\%, na amostragem correspondente a faixa de 2002 a 2005.

Por fim, notam a menor utilização de cláusulas restritivas ao financiamento das emissoras, diferentemente do observado no estudo inicial. Em contrapartida, os autores relatam uma maior rigidez em cláusulas relativas à mudança no controle da companhia emissora e não constituição de garantias reais, por parte da companhia emissora.

\footnotetext{
${ }^{59}$ SAITO, Richard et al. Governança Corporativa Embutida nas Escrituras de Debêntures Emitidas no Brasil. Revista de Administração da USP. São Paulo: RAUSP, 2008. p, 280 - 292.
} 


\title{
Em estudo recente, LUIZ FERNANDO DE PAULA e JOÃO ADELINO
}

DE FARIA JR. promovem explicações posteriores, analisando os fatores macroeconômicos e institucionais que afetam o crescimento do mercado de títulos de dívida corporativa. Assim, sintetizam os autores:

\begin{abstract}
"Como sugerido, o ambiente macroeconômico e a política econômica - crescimento da economia, inflação, política de juros, movimento da taxa de câmbio etc. - tem um papel fundamental na determinação da demanda e oferta por títulos e nas condições (montante emitido, remuneração, maturidade etc.) pelos quais os títulos são ou poderão ser emitidos. Do lado do ofertante de títulos corporativos (a empresa), o crescimento econômico (que aumenta a possibilidade de aumento de vendas e lucros, permitindo gerar renda para saldar compromissos financeiros assumidos) e o comportamento das taxas de juros (custo do crédito bancário e custo de oportunidade do capital) e de câmbio (preço fundamental na determinação das relações externas da empresa, por exemplo, para exportações e na determinação do custo de dívida externa) são fundamentais para definir a oferta de títulos. Do lado dos demandantes de títulos, além do ambiente macroeconômico em geral, a política de juros do banco central afeta de forma importante o grau de aversão a riscos dos investidores: uma expectativa de juros futuros elevados aumenta a preferência por moeda e ativos de alta liquidez, enquanto que uma expectativa de queda na taxa de juros futura aumenta a preferência por títulos de renda fixa". ${ }^{60}$
\end{abstract}

Os autores sugerem, ainda, que o mercado brasileiro teria algumas particularidades, qual seja o histórico de instabilidade e alta inflação (no mesmo sentido dos estudos acerca das cláusulas de debêntures) características de períodos stop and go, que contribui para a formação de um perfil de dívida de curto prazo, o que - além do estoque de títulos atrelados à taxa SELIC e a DI - retardaria ao estabelecimento de um mercado forte para títulos privados. No mais, o estoque de Letras Financeiras do Tesouro (LFT), atrelado à SELIC, conforme será descrito abaixo, corroboraria a este cenário.

Semelhantemente, ERNANI TEIXEIRA FILHO e LUIZ MACAHYBA apontam que alternativas para o financiamento bancários, e meios de financiamento de longo prazo, compõem parte da demanda brasileira no mercado de dívida. Nesse ponto, se destaca o papel desempenhado pelo

${ }^{60}$ PAULA, Luiz Fernando de; FARIA JR., João Adelino de. Mercado de Títulos de Dívida Corporativa Privada no Brasil: Aspectos estruturais e evolução recente. Revista de Economia Contemporânea. Vol. 16. Rio de Janeiro, n. 1, jan-abr. 2012. p, 110. 
Banco Nacional do Desenvolvimento (BNDES), o qual participa de cerca de $67 \%$ das operações de crédito superiores a 5 anos, no Brasil ${ }^{61}$.

Cabe, ainda, a conceituação da forma de utilização das debêntures no cenário atual. Dessa forma, nota-se que as emissões de debêntures, no Brasil, segundo dados da ANBIMA $^{62}$, já representam cerca de $50 \%$ das emissões domésticas. É evidente, assim, sua relevância no mercado de capitais nacional.

Portanto, cabe demonstrar, inicialmente, que não obstante a larga utilização das debêntures no Brasil, grande parte de sua utilização advém do refinanciamento do passivo do emissor, o que corresponde a cerca de $36,7 \%$ das emissões, o qual se faz evidente no Gráfico 3.

\section{Gráfico 3 - Destinação do Recursos}
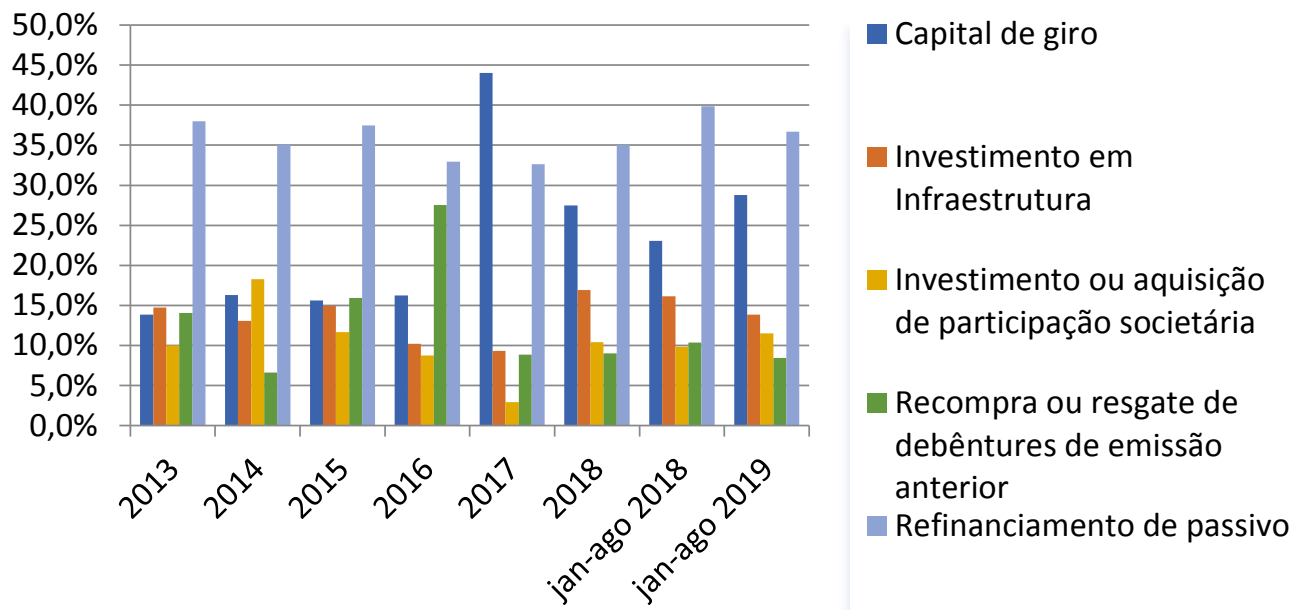

Fonte: ANBIMA, Elaboração Própria.

De maneira semelhante, pode-se observar a constituição de capital de giro como a segunda função dominante das debêntures no Brasil. Ponto interessante é o aparecimento do investimento em infraestrutura na terceira posição, o que pode ecoar um sucesso da Lei 12.431/11.

\footnotetext{
${ }^{61}$ TORRES FILHO, Ernani Teixeira; MACAHYBA, Luiz. O Elo Perdido. O Mercado de Títulos de Dívida Corporativa no Brasil: Avaliação e Propostas. São Paulo: Instituto de Estudos para o Desenvolvimento Industrial - IEDI/Instituto Talento Brasil, 2012. p, 27.

${ }^{62}$ ASSOCIAÇÃO BRASILEIRA DAS ENTIDADES DOS MERCADOS FINANCEIROS E DE CAPITAIS. Boletim de Renda Fixa. Disponível em < https://www.anbima.com.br/pt_br/informar/relatorios/mercado-de-capitais/boletim-de-mercado decapitais/debentures-ja-representam-quase-50-das-emissoesde20198A2AB2916D03F1C6016D161EF87365B5.htm >. Data de acesso (14 de setembro de 2019).
} 
Historicamente, ainda, em se tratando da forma de remuneração das emissões, pode-se notar um predomínio pela utilização da taxa de Depósitos Interbancários - DI, como indexador das emissões (Gráfico 4). Contudo, alterna-se entre a utilização do DI com um valor pré-fixado (spread), ou puramente um percentual sobre o mesmo ${ }^{63}$.

A taxa DI, dessa forma, é representativa das operações entre os bancos no sistema financeiro. Essas operações, que são liquidadas na CETIP, constituem taxa praticada por estas instituições, em empréstimos de curto prazo, usualmente um dia $^{64}$.

O IPCA - Índice Nacional de Preço ao Consumidor Amplo -, por outro lado, visa a captar a inflação incidente em determinado grupo de produtos ou serviços comercializados no varejo. Considerando as emissões de debêntures, no Brasil, o IPCA representou 16,3\% das emissões em 2019.

Gráfico 4 - Remuneração de Emissões: Indicadores por Volume

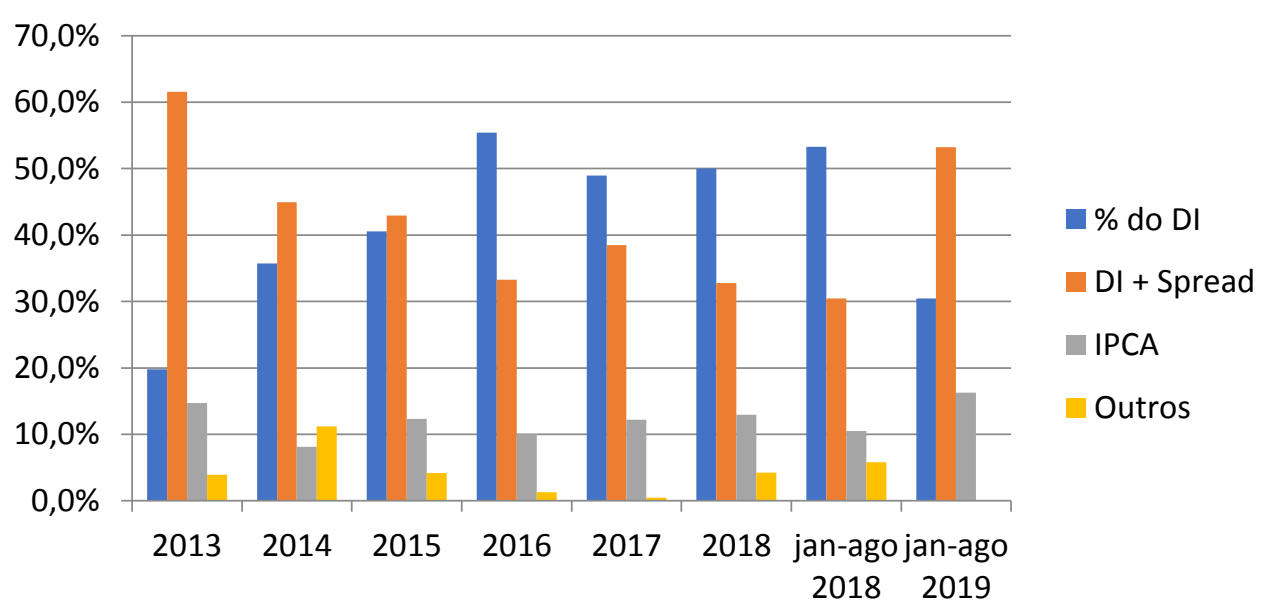

Fonte: ANBIMA, Elaboração Própria

\footnotetext{
${ }^{63}$ Em 2019, conforme dados da ANBIMA, a taxa mínima percentual praticada foi de $100 \%$ do DI, enquanto a média foi de $103,7 \%$, e máxima de $170 \%$. ASSOCIAÇÃO BRASILEIRA DAS ENTIDADES DOS MERCADOS FINANCEIROS E DE CAPITAIS. Boletim de Renda Fixa. Disponível em < https://www.anbima.com.br/pt_br/informar/relatorios/mercado-decapitais/boletim-de-mercado de-capitais/debentures-ja-representam-quase-50-das-emissoesde20198A2AB2916D03F1C6016D161EF87365B5.htm >. Data de acesso (14 de setembro de 2019).

${ }^{64}$ ASSAF NETO, Alexandre. Mercado Financeiro. 14 ${ }^{a}$ Edição. São Paulo: Atlas, 2019. p, 167.
} 
As garantias, por sua vez, podem representar a expectativa do público investidor sobre a probabilidade de default, de um dado emissor, e constituem ponto interessante para o estudo acadêmico. Racionalmente, a garantia é exigida sempre que o risco suportado pelo subscritor dos títulos for elevado, ou, no mínimo, seja percebido dessa forma.

$\mathrm{Na}$ amostra coletada pela ANBIMA, contudo, nota-se que a maior parcela das debêntures emitidas no Brasil conta apenas com garantias quirografárias, ou quirografária com garantia adicional. Todavia, não é possível aduzir, na totalidade do argumento, que a inexistência de garantias mais robustas, como comportamento dominante, signifique a baixa expectativa de inadimplemento.

Como já mencionado nos estudos acima, existem mecanismos contratuais de limitação do risco do investidor, sem falar-se propriamente em garantias, os quais foram historicamente praticados no Brasil. Nesse ponto, deve-se menção às limitações de disposição do ativo, bem como eventual cláusula de vencimento antecipado, recontratação ou prêmio pelo risco.

De todo modo, ainda se observa que as garantias reais são utilizadas, mesmo que em menor representatividade. Nota-se, entretanto, a utilização nula das garantias subordinadas e flutuante, conforme os dados da ANBIMA.

Gráfico 5 - Distribuição de Garantia por Volume (R\$)

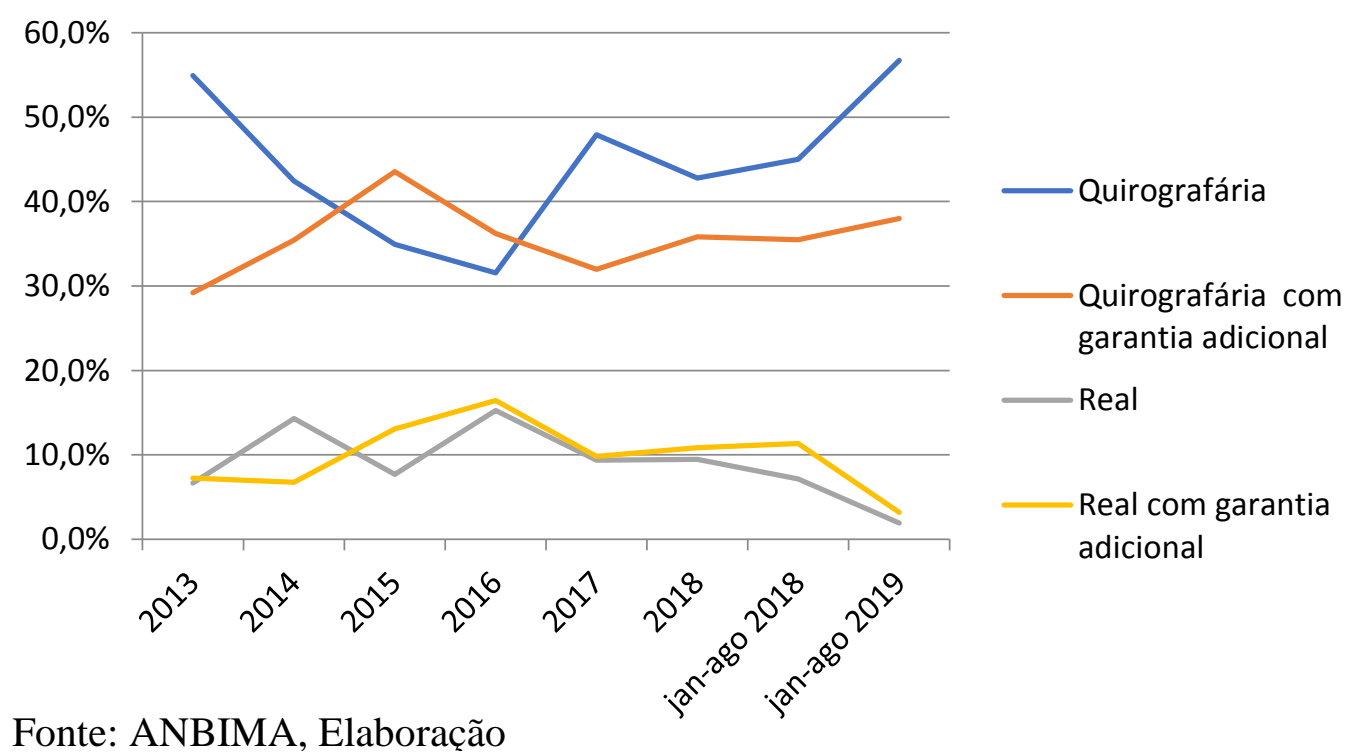


Quanto à forma de distribuição das debêntures, consagram-se duas formas de distribuição no ordenamento brasileiro, como mencionado acima. Assim, podem se dirigir ao público geral, por meio da ICVM 400, ou, valendo-se da regra da ICVM 476, ser realizada por esforços restritos.

Nessa linha, há grande relevância prática na diferenciação do tipo de oferta, em virtude da necessidade de registro prévio na CVM, em se tratando da ICVM $400^{65}$, a qual se encontra dispensada, por meio da ICVM 476, sendo esta somente comunicada à CVM no prazo de cinco dias de seu início. Visto essa lógica de registro, as ofertas realizadas sob a ótica da ICVM 476 serão destinadas exclusivamente a investidores profissionais, conforme regra de seu $\operatorname{artigo} 2^{\circ}$.

Adicionalmente, a ICVM 476 determina a procura de no máximo 75 investidores, com subscrição de no máximo $50\left(\operatorname{art} .3^{\circ}\right)$. Após a subscrição, é restringida a negociação dos ativos em mercado secundário pelo prazo de 90 dias, contados a partir de cada subscrição ${ }^{66}$.

\footnotetext{
65 "A norma de 2003 simplificou e desburocratizou o procedimento de registro de ofertas públicas de distribuição de valores mobiliários, sem descuidar do tratamento equitativo aos destinatários da oferta, por meio da ampla divulgação de todas as informações relevantes (art. $1^{\circ}$ da Instrução CVM n. 400)". CARVALHOSA, Modesto. Comentários à Lei de Sociedades Anônimas - $1^{\circ}$ Volume. 5a Edição. São Paulo: Saraiva, 2007. p, 602

66 "Art. 13. Os valores mobiliários ofertados de acordo com esta Instrução somente podem ser negociados nos mercados regulamentados de valores mobiliários depois de decorridos 90 (noventa) dias de cada subscrição ou aquisição pelos investidores, salvo nas hipóteses:

I - de negociações com ações, bônus de subscrição, certificados de depósito de ações e certificados de depósito de valores mobiliários no âmbito de programa de BDR Patrocinado Nível I, Nível II e Nível III; e

II - do lote objeto de garantia firme de colocação pelos coordenadores indicados no momento da subscrição, nas ofertas públicas dos valores mobiliários descritos nos incisos I, III, V e VI do $\S^{\circ}$ do art. $1^{\circ}$, observados, na negociação subsequente, os limites e condições previstos nos arts. $2^{\circ}$ e $3^{\circ}$ desta instrução.”
} 
Gráfico 6 - Distribuição Percentual de Ofertas de Distribuição

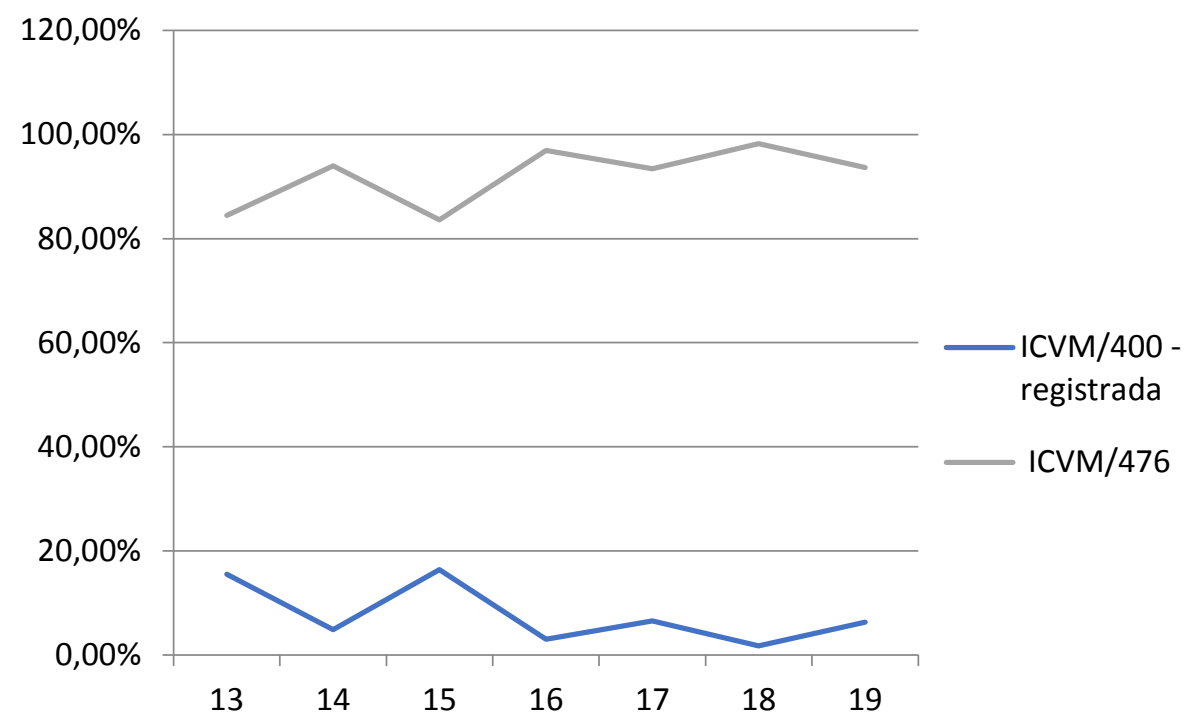

Fonte: ANBIMA, Elaboração Própria

Nessa linha, observa-se, no Gráfico 6, a prática predominante no mercado brasileiro de utilização de distribuição por esforços restritos. Desconsidera-se, ainda, os casos de ICVM 400 dispensadas, visto a baixa ocorrência.

Pelo exposto, nota-se que o mercado de debêntures brasileiro demonstra um padrão de evolução. De todo modo, como será destacado no Capítulo 3, estudos destacam a necessidade de melhorias em determinadas pautas, que contornam a adequação institucional às necessidades de mercados.

\section{II.2. O Papel do Underwriter}

Da lógica de captação de recursos junto ao público investidor, pressupõese a participação de instituição financeira classificada como underwriter (ou coordenadores da oferta). Essa é a atividade de intermediação financeira, usualmente realizada por instituições especializadas, como bancos de investimento, corretoras e distribuidoras. Nesse ponto, ressalta NELSON EIZIRIK:

"A função econômica essencial do underwriter é a de servir como um elemento de aproximação entre a empresa que emite publicamente os valores mobiliários e o 
público investidor. Nesta linha, ressalta sua atuação como empresa especializada, apta a assessorar a companhia emissora em todas as etapas do lançamento ao público de seus valores mobiliários" ${ }^{67}$.

O underwriter, assim, participa de múltiplas etapas da emissão, desde a decisão e estudo de viabilidade da operação, até o assessoramento com o registro na CVM, e elaboração dos documentos publicitários. Dessa forma, uma das funções que desempenhará o underwriter, em conjunto com a companhia emissora, é a de fixação do preço de emissão.

Dado a importância da atividade, não é qualquer instituição que pode exercer a função de underwriter. Assim, define a Lei ${ }^{\circ}$ 6.385/76, em seus artigos $19, \S 4^{\text {o68 }}$, e $15^{69}$, que a intermediação deve ser realizada por instituição financeira autorizada a participar do sistema de distribuição. Pode, ainda, o BNDES atuar como underwriter, visto que há previsão na Lei $\mathrm{n}^{\circ}$ 5.662/71 de o banco realizar operações bancárias necessárias para o desenvolvimento nacional.

É facultado, da mesma forma, que a operação de underwriting seja realizada por um conjunto de instituições, em oposição a uma única, o que se caracteriza como consórcio de intermediadores. A razão de ser desta prática é a repartição de risco em certas emissões em que se coloque um montante elevado de valores mobiliários ao público. De todo modo, em determinadas

\footnotetext{
${ }^{67}$ EIZIRIK, Nelson. Aspectos Modernos do Direito Societário. Rio de Janeiro: Renovar, 1992. p. 28.

68 “Art . 19. Nenhuma emissão pública de valores mobiliários será distribuída no mercado sem prévio registro na Comissão.

[...]

$\S 4^{\circ}$ - A emissão pública só poderá ser colocada no mercado através do sistema previsto no Art. 15, podendo a Comissão exigir a participação de instituição financeira."

69 “'Art . 15. O sistema de distribuição de valores mobiliários compreende:

I - as instituições financeiras e demais sociedades que tenham por objeto distribuir emissão de valores mobiliários:

a) como agentes da companhia emissora;

b) por conta própria, subscrevendo ou comprando a emissão para a colocar no mercado;

II - as sociedades que tenham por objeto a compra de valores mobiliários em circulação no mercado, para os revender por conta própria;

III - as sociedades e os agentes autônomos que exerçam atividades de mediação na negociação de valores mobiliários, em bolsas de valores ou no mercado de balcão;

IV - as bolsas de valores.

V - entidades de mercado de balcão organizado.

VI - as corretoras de mercadorias, os operadores especiais e as Bolsas de Mercadorias e Futuros; e VII - as entidades de compensação e liquidação de operações com valores mobiliários.”
} 
ocasiões, o consórcio pode ser resultado de baixa competitividade do setor, que gera ineficiências no mercado ${ }^{70}$.

No mercado brasileiro, ainda, nota-se que a atividade de intermediação de emissões de debêntures é amplamente concentrada. Nessa linha, argumentam ANTONIO GLEDSON DE CARVALHO e FELIPE TUMENAS MARQUES:

\begin{abstract}
"Underwriting: unlike other bond markets, where underwriting of bonds is usually competitive and dominated by international investment banks (Manconi et al., 2018; and Carbo-Valverde et al., 2016), underwriting in the Brazilian bond market is dominated by only two local universal banks. Table 6 reports underwriting in the Brazilian bond market. Bradesco has the largest share: $53.3 \%$ of proceeds and $49.6 \%$ of issues. Itau-Unibanco has $43.5 \%$ of proceeds and $45.5 \%$ of issues. Banco do Brasil comes next with only $0.8 \%$ of proceeds and $0.4 \%$ of issues. This pattern is consistent across Regular and Infra bonds, and CVM-400 and CVM-476 issues."
\end{abstract}

Feitas essas considerações, o underwriting pode ocorrer mediante certas modalidades, quais sejam: por garantia firme (straight); residual (stand by); ou melhores esforços (best efforts $)^{72}$. Assim, a depender da modalidade escolhida, a instituição financeira assume responsabilidades e riscos particulares.

De partida, o underwriting por garantia firme é aquele no qual há o compromisso assumido pela instituição financeira de subscrição da totalidade dos valores mobiliários emitidos, que serão posteriormente revendidos ao público. A instituição financeira subscreve a totalidade dos títulos, e paga a emissora, nessas condições. Nesse caso, evidentemente, o risco da instituição financeira é elevado, visto que não há compensação caso a colocação pública não seja frutífera, ou o empreendimento financeiro não ocorra como o esperado.

Em se tratando do underwriting stand by (ou residual), a instituição adquire a obrigação de subscrever os títulos não subscritos pelo público, após a colocação. Pode acontecer, da mesma forma, que o underwriter se

\footnotetext{
${ }^{70}$ EIZIRIK, Nelson. Op. Cit., p, 38.

71 CARVALHO, Antonio Gledson de; MARQUES, Felipe Tumenas. The Microstructure of the Brazilian Market for Corporate Bonds. Fundação Getúlio Vargas. São Paulo: FGV, 2019.

${ }^{72}$ EIZIRIK, Nelson. Op. cit, p, 30.
} 
comprometa a subscrição de uma porcentagem previamente estabelecida dos valores mobiliários distribuídos, o que não é o usual. Em regra, na modalidade residual, a instituição financeira se detém a obrigação de compra da parcela não subscrita dos valores mobiliários emitidos.

Por fim, faz-se menção à modalidade de underwriting por melhores esforços (best efforts). Nesse, a instituição financeira tem somente obrigação de meio, empenhar seus melhores esforços, não partilhando o risco do empreendimento com o emissor. Ele é, dessa forma, somente um prestador de serviço, não agindo como garantidor da oferta.

Independentemente da modalidade, contudo, nota-se que o underwriter será o agente responsável por intermediar a oferta, facilitando sua distribuição. Ele exerce função de grande importância, assim, visto que sem a participação do público investidor, a captação de recursos estaria amplamente frustrada.

\section{II.3. Competitividade dos Títulos Públicos}

Convém menção, ainda, da relação entre títulos públicos e privados. Dessa forma, argumenta-se, como ponto de partida, que o estabelecimento de um mercado de dívida pública cria condições estruturais para consolidação de um mercado de títulos privados. De todo modo, a experiência brasileira demonstra determinadas particularidades.

Argumenta-se, assim, inicialmente, que a relação entre CETIP e Sistema SELIC, por exemplo, contribui para essa dinâmica, visto que ambas possibilitam a desmaterialização dos títulos, e simplificam a negociação dos ativos. Semelhantemente, a estrutura de juros e base de cálculo posiciona os dois mercados na mesma direção, padronizando a forma de operação.

Entretanto, ao contrário do que se orienta, a alta taxa de juros praticadas pelos títulos públicos, atrelada à alta liquidez característica deste mercado, 
cria condições de difícil competitividade para os emissores privados ${ }^{73}$. Acrescenta-se a esse cenário, ainda, questões de natureza tributária, visto que foi praticado no Brasil isenção de imposto de renda, em se tratando de investidores não residentes, aos ganhos auferidos em cima de títulos públicos federais.

Nessa linha, ao que se argumenta, é apresentado uma relação oposta entre os mercados de dívida pública e privada no Brasil, dado as características da primeira. Assim, orienta LUIZ FERNANDO DE PAULA e JOÃO ADELINO DE FARIA JR:

\begin{abstract}
"Em realidade, não apenas parece não haver complementaridade entre os dois mercados, como parece haver evidências da existência de concorrência entre os mesmos. As condições vantajosas oferecidas pelos títulos públicos federais indexados a variáveis mais voláteis do mercado - taxa de juros, taxa de câmbio e/ou taxa de inflação - ao mesmo tempo em que oferece ao demandante de título uma proteção contra os riscos de juros, cambial ou de perda inflacionária, lhe proporciona papéis que combinam rentabilidade, liquidez e baixo risco." ${ }^{" 74}$
\end{abstract}

Continua o autor delineando a forma como os títulos públicos são estruturados. Ressalta-se, nesse quadro, o papel das Letras Financeiras do Tesouro (LFT). Essas, por sua vez, são títulos indexados a taxa Selic, e com duração zero ${ }^{75}$. Dessa forma, impactam a emissão de debêntures, como títulos privados, na seguinte condição:

"A existência de títulos indexados a taxa Selic acaba por contaminar a emissão primária de títulos de dívida privada com a lógica de overnight. Mais especificamente, as LFTs influenciam as condições de emissão dos TDP, em função do fato de que tais títulos: (i) como qualquer outro título público, tem risco de default praticamente nulo, por serem garantidos pelo Tesouro; (ii) especificamente, no caso das LFTs é o único título

\footnotetext{
73 “Na prática, os papéis privados continuam se vendo obrigados a concorrer com ativos financeiros públicos que oferecem taxa de juros real e nominal ainda muito elevadas e são percebidos pelos investidores como livres de risco de crédito e de recompra relativamente fácil. Esse quadro manteve os mercados de títulos públicos e de títulos privados com níveis de desenvolvimento bastante desiguais." TORRES FILHO, Ernani Teixeira; MACAHYBA, Luiz. O Elo Perdido. O Mercado de Títulos de Dívida Corporativa no Brasil: Avaliação e Propostas. São Paulo: Instituto de Estudos para o Desenvolvimento Industrial - IEDI/Instituto Talento Brasil, 2012. p, 36.

${ }^{74}$ PAULA, Luiz Fernando de; FARIA JR., João Adelino de. Op. Cit.,. p, 116.

75 "Pode-se dizer, portanto, que a LFT tem "duração zero", e que se procure diferenciar este conceito de "duração" (elasticidadade do preço do papel relativamente à taxa de juros) do (prazo médio) do vencimento da dívida pública. Em si, a singularidade deste instrumento, e sua enorme disseminação, já seriam suficientes para introduzir muitas questões práticas e conceituais sobre o funcionamento da política monetária). FRANCO, Gustavo. Notas Sobre Crowding Out, Juros Altos e Letras Financeiras do Tesouro. Rio de Janeiro, 2005. p.1.
} 
de dívida livre do risco de mercado, por não sofrer apreciação/depreciação em seu preço - ou seja, não têm embutido como qualquer título prefixado um risco de mercado; (iii) como se não bastasse, tais títulos têm oferecido taxas de remuneração elevadas, ainda que inferiores aos títulos prefixados, em função da política de juros altos que tem sido praticada pelo BCB, mesmo sob o regime de metas de inflação."

Nessa linha, em estudo sobre o impacto das LFTs na política monetária, GUSTAVO FRANCO analisa as repercussões da existência de um instrumento com esse funcionamento, no mercado brasileiro. Para o autor, as LFTs representam a institucionalização de uma prática de mercado, em tempos de alta inflação, em que se aplicava no overnight ("emprestar ou tomar emprestado por um dia - com o risco (lastro em títulos) do Tesouro Nacional").

De todo modo, com a modificação da estrutura inflacionária, o autor argumenta que, desta dinâmica, é produzida uma exclusão do setor privado no processo de concorrência pela poupança popular. Sublinha GUSTAVO FRANCO, dessa forma:

\begin{abstract}
"É de se notar, porém, que, em vista da ampla e prolongada exposição do organismo econômico a esta doença, a exclusão do setor privado da disputa pela poupança nacional, ou o "racionamento" da poupança disponível em benefício do financiamento do governo, acaba sendo feito não apenas através de mecanismos de preço (via juros excessivamente elevados), mas também via mecanismos de natureza regulatória (como os das "exigibilidades", "direcionamentos" e sistemas de poupança compulsória) e mecanismos associados aos prazos da dívida pública, como os ensejados pelas LFTs e práticas do $\mathrm{BC}$ acima descritas. Os depósitos compulsórios, anormalmente altos no Brasil, "direcionamentos de crédito" tipicamente brasileiros, e mecanismos de "poupança compulsória" também muito caracteristicamente nossos (como no caso dos recursos que fluem para o FGTS e para o BNDES e refluem seletivamente para a economia com juros "subsidiados"), não podem deixar de ser compreendidos como instrumentos de financiamento do governo (ou de políticas públicas de interesse do governo), ou de disputa de recursos com o setor privado em um contexto de dominância fiscal." $" 76$
\end{abstract}

Nota-se, portanto, frente à dinâmica de crescimento do mercado de títulos privados, especialmente de debêntures, a obstrução causada pela concorrência dos títulos públicos, que, evidentemente, corresponde à política econômica adotada por um governo que vivia condições fáticas

\footnotetext{
${ }^{76}$ Ibid., p. 5.
} 
significativamente diferentes. Contudo, visto os impactos que causam no presente, deve-se estudar maneiras de mitigar eventual influencia negativa.

\section{II.4. Derivativos de Crédito}

Apesar de não constituirem particularidade do mercado brasileiro, merece-se algumas notas sobre a função dos derivativos de crédito, sobretudo o Credit Default Swap (CDS), na formação do mercado de debêntures. A atenção a esse tipo de prática, assim, torna-se relevante, entre outras causas, devido à sua relação com o mapeamento de riscos, inclusive, como narra a literatura, tendo parte ativa na crise americana de $2008^{77}$. Dessa forma, o estabelecimento de um mercado de crédito saudável, pressupõe, ainda, a discussão sobre a participação dos derivativos nesta dinâmica.

Assim, conforme se reporta a literatura, o CDS é um instrumento pelo qual se transfere o risco de um evento de crédito, inerente a um ativo ou operação, para um terceiro. Dessa forma, uma das partes do contrato toma proteção contra um risco de crédito, enquanto a outra vende garantia. Semelhantemente, define JOHN C. HULL:

\footnotetext{
"The most popular credit derivative is a credit default swap (CDS). This was introduced in Section 7.12. It is a contract that provides insurance against the risk of a default by particular company. The company is known as the reference entity and a default by the company is known as a credit event. The buyer of the insurance obtains the right to sell bonds issued by the company for their face value when a credit event occurs and the seller of the insurance agrees to buy the bonds for their face value when a credit event occurs. 1 The total face value of the bonds that can be sold is known as the credit default swap's notional principal." 78
}

\footnotetext{
77 “Em uma descrição necessariamente simplificada, pode-se afirmar que o uso generalizado dos derivativos de crédito nos Estados Unidos acabou, durante a crise, produzindo um efeito inesperado: o descumprimento de uma obrigação por uma instituição com problemas de liquidez deflagrava a obrigação do terceiro, que assumira aquele risco contra o pagamento de um prêmio. Não obstante, muitas vezes aquele terceiro era uma instituição que tinha que lidar com seus próprios problemas de liquidez. Em suma, instrumentos criados pelo mercado para proteção (e largamente utilizados para finalidades especulativas), acabaram permitindo, como acima referido, o aprofundamento da crise". YAZBEK, Otávio. Crise, inovação e regulação no mercado financeiro - considerações sobre a regulamentação do mercado de derivativos de balcão. In:. SOUZA JÚNIOR, Francisco Satiro de. Mercado de Capitais. São Paulo: 2013. p, 8.

78 HULL, John C. Options, Futures and Other Derivatives. 9th Edition. Inglaterra: Pearson Education Limited, 2015. p, 594.
} 
Dessa forma, a parte tomadora do CDS fará pagamentos periódicos, até o vencimento do derivativo, ou a ocorrência do evento de crédito $^{79}$, tendo um spread final correspondente à diferença entre o valor total pago a parte vendedora, e o notional value do swap. Nessa dinâmica, mitiga-se o risco de crédito, visto que na ocorrência do evento estabelecido no contrato a parte vendedora deverá pagar a compradora o valor do notional, enquanto na não ocorrência a tomadora terá um spread.

O CDS torna-se interessante uma vez que não necessita da anuência da companhia cujo risco de crédito se mitiga (reference entity), e se consubstancia em um título autônomo, passível de negociação independente, no qual se isola o risco de crédito. Por esse razão, além de proteção contra exposição a um evento de crédito, o CDS pode ser atrativo, também, para fins especulatórios.

Em dados de 2011, em vista o mercado brasileiro, uma média mensal de 14,7 instituições eram responsáveis pela negociação de CDS no país, que totalizava o valor nocional diário correspondente a 575 milhões de dólares, em referência ao mesmo período ${ }^{80}$. Dessa forma, nota-se um mercado concentrado, responsável por um volume grande de ativos negociados, e cuja função principal é a mitigação do risco de operações de crédito.

Nesse sentido, GUSTAVO DE CARVALHO SEIGNEMARTIN sustenta que o CDS, em alguns casos, pode ter um efeito contrário do que se defende. Assim, o argumento é de que a transferência do risco de crédito, de fato, não o elimina. Nessa lógica, com a concentração do mercado, o risco acaba centralizado em poucas instituições - geralmente grandes players.

Dessa forma, como linha geral, o autor argumenta que a utilização do CDS pode gerar incentivos para instituições tomarem exposição excessiva a risco, considerando um sistema de contrapeso às suas obrigações futuras. De

\footnotetext{
${ }^{79}$ A conceituação do evento de crédito é de grande relevância, nesse caso, de forma que as partes podem divergir sobre sua ocorrência. Em casos menos claros, em que não seja evidente a natureza do evento, o pagamento do principal pode tratar-se de um risco por si mesmo, uma vez que dependerá de provas.

${ }^{80}$ SEIGNEMARTIN, Gustavo de Carvalho. The Rise of Credit Default Swaps and the Changing Political Environment of Sovereign Debt Markets. APSA 2011 Annual Meeting. Toronto, 2011. p, 15.
} 
todo modo, conforme se argumenta, o colchão para tal passivo, pode, mas não necessariamente será, inseguro, uma vez que se baseia em cenários desconhecidos, associados também ao risco de contraparte.

No ordenamento jurídico brasileiro, os derivativos, amplamente considerados, são caracterizados como valores mobiliários, e, portanto, regulados pela CVM. Nesses termos, faz-se menção à Instrução CVM nº 461, de 23 de outubro de 2007, que disciplina os mercados de bolsa e balcão organizado, definindo o regime jurídico das instituições que nele atuam, e à Instrução CVM n n $^{\mathrm{o}}$ 467, de 10 de abril de 2008, que dispõe sobre os procedimentos de aprovação dos contratos de derivativos ${ }^{81}$.

Em específico aos derivativos de crédito, a regulação, no Brasil, se dá por meio da Resolução CVM n 2.933, de 28 de fevereiro de 2002, e da Circular BCB $\mathrm{n}^{\circ}$ 3.106, de 10 de abril de 2002. Assim, faculta-se a negociação sob duas modalidades, CDS (acima mencionado) e total return swap. OTÁVIO YAZBEK, nesse sentido, os diferencia da seguinte forma:

\begin{abstract}
"A rigor, ao menos na forma aqui adotada, tais operações diferenciam-se apenas em razão da forma de remuneração do adquirente do risco, como a seguir se verá. Nos dois casos, trata-se de operação em que uma instituição, detentora de risco de crédito decorrente de suas atividades operacionais (relacionadas no parágrafo $3^{\circ}$, II, do artigo $1^{\circ}$ da Resolução acima referida), negocia aquele risco com um terceiro, também instituição financeira (a tal contraparte receptora do risco de crédito), sem, no entanto, transferir o ativo subjacente (as relações de crédito propriamente ditas)." ${ }^{92}$
\end{abstract}

Como se expõe, nesse sentido, deve-se ter em mente, sobretudo quando se discute um mercado em expansão, formas de manter este crescimento em níveis de maturidade que não, futuramente, prejudiquem sua sustentação. Nessa lógica, a história é repleta de exemplos que comprovam a má utilização

\footnotetext{
81 “'Desta forma, os modelos de contratos derivativos destinados à negociação nos chamados mercados organizados devem ser previamente aprovados pela CVM, enquanto que aqueles que serão negociados diretamente entre as partes e meramente registrados em mercado de balcão organizado (como adiante se verá) devem ser aprovados apenas pela entidade administradora do correspondente mercado, que deverá observar determinados critérios." YAZBEK, Otávio. Crise, inovação e regulação no mercado financeiro - considerações sobre a regulamentação do mercado de derivativos de balcão. In: Mercado de Capitais. SOUZA JÚNIOR, Francisco Satiro de. São Paulo: 2013. p, 19. ${ }^{82}$ YAZBEK, Otávio. O Risco de Crédito e os Novos Instrumentos Financeiros. In: WAISBERG, Ivo; FONTES, Marcos Rolim Fernandes (coords.). Contratos Bancários. São Paulo: Editora Quartier Latin, 2006. p, 330.
} 
de produtos financeiros, e, considernado o movimento de complexificação do mercado, exigirá ainda maior atenção. Assim, considerado o desenvolvimento de um mercado de crédito, o CDS torna-se um produto relevante. 


\section{CAPÍTULO III - DESAFIOS AO DESENVOLVIMENTO DO MERCADO DE DEBÊNTURES}

Uma vez descritas as características jurídicas das debêntures no Brasil, bem como exposta sua microestrura de mercado, torna-se relevante a exposição das necessidades, e obstáculos, ao desenvolvimento de um mercado de debêntures, sobretudo que satisfaça a demanda das companhias emissoras e do público investidor ${ }^{8384}$.

Nessa linha, estudos demonstram a necessidade do estabelecimento de um mercado secundário líquido (item 1) e de formas de financiamento para pequenas e médias empresas (item 2$)^{85}$. Dessa forma, neste Capítulo, serão analisados os pontos em referência, visto seu impacto na dinâmica de negociação de debêntures ${ }^{86}$.

\section{III.1. Liquidez no Mercado Secundário de Debêntures}

Nas ciências da natureza, liquidez é o estado de separação entre moléculas. Um corpo líquido, assim, é capaz de fluir no meio, se adaptando ao recipiente no qual está inserido ${ }^{87}$.

Na dinâmica de mercado, de outra forma, liquidez é o termo usualmente utilizado para designar a capacidade de conversão de um ativo em moeda, que por definição é líquida. Nesses termos, AMIHUD e MENDELSON ${ }^{88}$ caracterizam a iliquidez como o custo para a execução imediata de ativo. Nesse caso, o vendedor parte de um trade-off, no qual deve escolher entre a

\footnotetext{
${ }^{83}$ COMISSÃO DE VALORES MOBILIÁRIOS. O mercado de dívida corporativa no Brasil: Uma análise dos desafios e propostas para seu desenvolvimento. Rio de Janeiro: CVM, 2019.

${ }^{84}$ INTERNATIONAL ORGANIZATION OF SECURITIES COMMISSIONS. Development of Corporate Bond Markets in the Emerging Markets. Espanha: IOSCO, 2011

${ }^{85}$ Estudos demonstram a existência de outros gargalos, como custo de operação, por exemplo, o que, contudo, é de díficil confirmação empírica.

${ }^{86}$ NASSR, Iota Kaousar; WEHINGER, Gert. Unlocking SME Finance through Market-Based Debt: Securitisation, Private Placements and bonds. OECD Journal: Financial Market Trends Volume 2014/2. França: 2015. p. 2.

${ }^{87}$ DICIONÁRIO PRIBERAM. Líquido. Disponível em < https://dicionario.priberam.org/liquido > Data de acesso (14, novembro e 2019).

88 AMIHUD, Yakov; MENDELSON, Haim. Asset pricing and the bid-ask spread. Journal of Financial Economics. Rochester, v.17, n.2, p. 223-250, 1986.
} 
execução imediata sujeita a preço de mercado, ou carregar o ativo em busca de um preço favorável.

$\mathrm{Na}$ literatura econômica, o risco de liquidez é frequentemente referido como um fenômeno multifacetado. Diante da dificuldade de conceituação, o INTERNATIONAL MONETARY FUND, atribui a mercados líquidos as seguintes características:

\begin{abstract}
"Liquid markets tend to exhibit five characteristics: (i) tightness; (ii) immediacy; (iii) depth; (iv) breadth; and (v) resiliency. Tightness refers to low transaction costs, such as the difference between buy and sell prices, like the bid-ask spreads in quote-driven markets, as well as implicit costs. Immediacy represents the speed with which orders can be executed and, in this context also, settled, and thus reflects, among other things, the efficiency of the trading, clearing, and settlement systems. Depth refers to the existence of abundant orders, either actual or easily uncovered of potential buyers and sellers, both above and below the price at which a security now trades. Breadth means the orders are both numerous and large in volume with minimal impact on prices. (...). Resiliency is a characteristic of markets in which new orders flow quickly to correct imbalances, which tend to move prices away from what is warranted by fundamentals. These terms reflects different dimensions of the extent to which an asset quickly and without significant costs can be transformed into legal tender." 89
\end{abstract}

FISHER, em artigo célebre, foi um dos primeiros exemplos na literatura a teorizar o impacto do risco na formação do preço de um bond. Para o autor, se tratando de investidores racionais, o prêmio referente ao risco seria dependente da probabilidade de insolvência do emissor, determinando a capacidade do investidor transformar seu ativo em moeda corrente ${ }^{90}$.

Conforme se averigua a hipótese teórica do risco de liquidez afetar o preço das debêntures, estudos conduzidos recentemente no Brasil apontam a possibilidade de a baixa liquidez no mercado secundário ser um dos motivos determinantes para o subdesenvolvimento do mercado em geral, conforme será analisado abaixo. No contexto internacional, demonstra-se que a liquidez não é condicionada ao tamanho e desenvolvimento do país, como verificado em Israel, um dos mercados mais líquidos no mundo ${ }^{91}$.

\footnotetext{
${ }^{89}$ SARR, Abdourahmane; LYBEK, Tonny. Measuring Liquidity in Financial Markets. IMF Working Paper WP/02/232. EUA: IMF, 2002. p, 4.

${ }^{90}$ FISHER, Lawrence. Determinants of Risk Premiums on Corporate Bonds. Journal of Political Economy. Chicago: vol. 67, 1959.

${ }^{91}$ COMISSÃO DE VALORES MOBILIÁRIOS. O mercado de dívida corporativa no Brasil: Uma análise dos desafios e propostas para seu desenvolvimento. Rio de Janeiro: 2019. p, 5.
} 
Pelo exposto, torna-se relevante a análise, neste item, da relação entre liquidez no mercado secundário de debêntures e a consolidação de um ambiente de negociação no Brasil, no qual se estimule a emissão e negociação de debêntures. Assim, será analisada a trajetória teórica da precificação do risco de liquidez, e como vem se tratando o assunto no Brasil e no exterior.

\title{
III.1.1. A relação entre Risco de Liquidez e Preço do Ativo
}

A teoria clássica de precificação de ativos, segundo referida por AMIHUD, MENDELSON, e PEDERSEN ${ }^{92}$, pressupõe a ausência de fricção no mercado, frictionless markets (ou perfect liquidity). Dado este pressuposto, é assumido ausência de custos de transação e que agentes de mercado tomam o preço como dado, não podendo influir em sua formação ${ }^{93}$.

Nesse ponto, SHARPE e LINTNER sugerem o Capital Asset Pricing Model (CAPM), referência na precificação de ativos. BLACK, JENSEN e SCHOLES, ao comentar tal modelo, estabelecem os seguintes pressupostos:

\begin{abstract}
"In the development of the asset pricing model it is assumed that (1) all investors are single period risk-averse utility of terminal wealth maximizers and can choose among portfolios solely on the basis of mean and variance, (2) there are no taxes or transactions costs, (3) all investors have homogeneous views regarding the parameters of the joint probability distribution of all security returns, and (4) all investors can borrow and lend at a given riskless rate of interest." 94
\end{abstract}

Tais condições, que simplificam o cálculo em referência, revelam-se, todavia, fictícias, dado que, se não impossível, é pouquíssimo provável a existência de um mercado que satisfaça tal modelo. De certa forma, ainda, o estabelecimento de um mercado pressupõe custos, quais sejam legais,

\footnotetext{
${ }^{92}$ AMIHUD, Yakov et al. Liquidity and Asset Prices. Foundations and Trends in Finance. Nova Iorque, 2005. p, 273.

${ }^{93}$ Nesse ponto, quando se fala de ausência de custos de transação, pressupõe-se, da mesma forma, que nenhum agente terá lucro com arbitragem de ativo, equilíbrio de mercado e atores eficientes. ${ }_{94}^{94}$ JENSEN, Michael et al. The Capital Asset Pricing Model: Some Empirical Tests. In: JENSEN, Michael. Studies in The Theory of Capital Markets. Praeger Publishers Inc. Nova Iorque, vol. 1, 1972, p, 1.
} 
operacionais, computacionais ou informacionais ${ }^{95}$, sem os quais não haveria mercado regulamentado, muito menos organizado.

Dessa forma, uma vez estabelecida a existência de custos de negociação no mercado, deve-se considerar o seu impacto na formação de preço dos ativos. Assim, as variáveis de iliquidez, em um mercado, podem ser caracterizadas como custos exógenos, como corretagem, taxas, ou processamento de ordens; e custos de demanda, referentes à ausência de compradores imediatamente disponíveis no mercado.

Desta noção se depreende, então, que a liquidez afetará o preço de um ativo sempre que um agente de mercado exigir compensação adicional por carregar um ativo, considerando os custos de negociação de compra e venda. Assim, em consequência, a função de desconto implica a consideração dos custos de transação esperados durante a vida útil do ativo, trazidas a valor presente. Nesse sentido, definem AMIHUD e MENDELSON:

"The basic idea is as follows. A risk-neutral investor who buys a security and expects to pay transaction costs when selling it, will take into account this when valuing the security. She knows that the buyer will also do that, and so on. Consequently, the investor will have to consider, in her valuation, the entire future stream of transaction costs that will be paid on the security. Then, the price discount due to illiquidity is the present value of the expected stream of transaction costs through its lifetime." ${ }^{96}$

Um estudo empírico relevante sobre o assunto foi proposto por AMIHUD e MENDELSON, no qual os autores analisaram o impacto na liquidez em títulos de dívida emitidos pelo governo americano - U.S. Treasury Notes and Bills. A comparação é feita utilizando esses ativos, tendo em vista que suportam o mesmo risco, equivalem-se durante uma parcela de sua vida útil e possuem o mesmo fluxo de caixa, o que permite o estudo segregado do impacto da liquidez.

${ }^{95}$ STIGLITZ e GROSSMAN relatam que na ausência de custos de informação nenhum agente teria estímulo a participar de um mercado, visto que não haveria recompensa para reunião de informação. GROSSMAN, Sanford J.; STIGLITZ, Joseph E. On the Impossibility of Informationally Efficient Markets. The American Economic Review. EUA: vol. 70, n.3, 1980.

${ }^{96}$ AMIHUD, Yakov et al. Liquidity and Asset Prices. Foundations and Trends in Finance. Nova Iorque, 2005. p, 279. 
Notes e bills, apesar de serem ambos emitidos pelo governo americano, são papéis significativamente diferentes. O primeiro é um título de dívida de curto prazo, enquanto o segundo é um bond de longo prazo, com pagamento de coupon e maturidade bem mais estendida. Contudo, nota-se que nos seis últimos meses da maturidade das bills, dado que não resta pagamento de coupon, eles se assemelham a títulos de curto prazo, assemelhado-se às notes. Dessa forma, a pesquisa foi conduzida justamente nesse período de seis meses de maturidade das bills, visto a simplificação do estudo isolado da liquidez.

Dessa forma, os autores demonstram que existe uma diferença significativa no mercado para ambos os títulos, sendo o mercado para bills significativamente mais líquido do que o de notes. Assim, se prescreve:

"The differences in liquidity are evidenced by the differences in the bid-ask spread, the brokerage fees, and the standard size of a transaction. The brokerage fee for bills is between $\$ 12.5$ and $\$ 25$ per $\$ 1$ million, compared with $\$ 78.125$ per \$1 million for notes (paid by the party initiating the transaction), 5 and the typical bid-ask spread on bills is of an order of $1 / 128$ of a point compared with $1 / 32$ on notes (both per $\$ 100$ face value). It is worth noting that this difference in bid-ask spreads cannot be attributed to the often-assumed problem of asymmetric information about fundamental values faced by market-makers because both instruments are affected by the same information. The difference in the spread represents transaction costs borne by dealers when trading notes because of the associated direct and inventory-related costs. Still, notes are far more liquid than stocks." 97

Assumido, então, a liquidez como fator relevante na formação do preço de um ativo, HOUWELING, MENTINK e VORST estabelecem método para quantificar a relação entre liquidez e yield, em mercado de títulos de dívida corporativos. Para tanto, os autores trabalham com oito métricas indiretas ("proxies") ${ }^{98}$ de liquidez, de modo a estudar sua capacidade de influir na formação de preço dos ativos ${ }^{99}$.

97 AMIHUD, Yakov; MENDELSON, Haim. Liquidity, maturity and the yields on U.S. government securities. Journal of Finance. Nova Iorque, 46, 1991. p, 1413.

98 Os autores defendem a utilização de métricas indiretas, ao invés de diretas - como volume de transações, frequência de transações e bid-ask spread - pelo fato de o mercado de bonds ser em grande parte um mercado de balcão não organizado (OTC). Dessa forma, tais dados podem ser de difícil acesso para a pesquisa.

99 HOUWELING, Patrick et al. Comparing possible proxies of corporate bond liquidity. Journal of Banking \& Finance. Amsterdam, v.29, n.6, p.1331-1358, June 2005. 
Toma-se o estudo dos autores como referência, nesse caso, tendo em vista que utilizam métricas comumente citadas na literatura, sem juízo de valor, e formam um modelo de teste como base. Ainda, como será referido em sequência, alguns estudos conduzidos no Brasil adotam esse método de pesquisa.

Assim, nesse modelo, constrói-se virtualmente um portfolio de títulos de dívida, e faz-se o teste de sua exposição a determinado proxy, utilizando modelos de regressão ${ }^{100}$. Apesar do estudo dos autores ter sido conduzido no mercado europeu, a construção das métricas é abstrata. Dessa forma, cabe a conceituação teórica do significado das proxies utilizadas.

De partida, o volume de emissão (issued amount) é um proxy habitual de liquidez. Assim, considera-se que largas emissões teriam frequência de negociações elevadas, visto a maior disponibilidade de ativos. $\mathrm{Na}$ literatura, faz-se menção a maiores emissões terem menor custo de informação, e dessa forma menor yield, visto que mais investidores teriam a capacidade de analisar as características do ativo.

Portanto, fala-se que uma emissão maior teria uma taxa de retorno menor, logo, o volume de emissão teria uma relação inversamente proporcional ao preço de um ativo ${ }^{101}$. Ainda em se tratando do issued amount, emissões menores podem ter melhor adaptabilidade à estratégia buy-and-hold ${ }^{102}$, que reduzem, sem dúvida, a frequência de negociação do ativo.

Tendo em vista a emissão de dívida por companhias abertas, consagra-se, ainda, a listagem como fator de liquidez. Nesse ponto, ao contrário do intuitivo, a literatura, em teste empírico, conforme HOUWELING,

100 "For each liquidity proxy, we construct $\mathrm{P}$, mutually exclusive portfolios by sorting all bonds on their 1 value of the liquidity proxy and assigning the first $100 / \mathrm{P} \%$ of the bonds to portfolio 1 , the next 100/P \% to portfolio 2, and so on, until the last 100/P \% of the bonds are assigned to portfolio $\mathrm{P}$. The $\mathrm{P}$ time series of portfolio yields are subsequently used in two regression models. In the first model, each portfolio has a constant liquidity premium. In the second model, the liquidity premium is time-varying and a function of the size of liquidity proxy." (HOUWELING, Patrick et al. Comparing possible proxies of corporate bond liquidity. Journal of Banking \& Finance. Amsterdam, v.29, n.6, p.1331-1358, June 2005, p.2)

${ }^{101}$ Poderia-se considerar esse ponto como iliquidity premium, conforme sugerido por Houweling, Mentink e Vorst. HOUWELING, Patrick et al. Op. Cit., p. 3.

${ }^{102}$ Buy-and-hold corresponde à estratégia de longo prazo, onde mantem-se o ativo na carteira até data do vencimento. 
MENTINK e VORST, relata que companhias de capital aberto teriam volume de negociação de dívida menor, em comparação com as de capital fechado, visto que nas primeiras, negocia-se dívida e equity, enquanto nas segundas dívida é o único instrumento de investimento disponível.

Em relação à idade do ativo, considera-se que quanto mais velha a emissão, maior a probabilidade de entrar em um portfolio buy-and-hold. Como argumento contrário, estipula-se que algumas emissões primárias estariam precificadas incorretamente, o que estimula a venda posterior. Considerando ambos os casos, não há como afirmar se a idade tem uma relação positiva ou negativa com a taxa de retorno de uma debênture. De todo modo, a idade é uma métrica frequentemente utilizada como proxy de liquidez.

SARIG e WARGA trabalham esta ideia, atestando a referida hipótese de que a liquidez de um bond tende a decair em função de sua idade. Os autores trabalham com duas séries de dados independentes, que demonstram a discrepância de preços em períodos de tempo. Segundo o estudo, se a idade fosse insignificante para a parametrização da liquidez, a discrepância deveria ser igualmente provável em bonds mais novos e mais velhos. Todavia, evidências empíricas comprovam a maior ocorrência de discrepância de preços em bonds mais velhos, significando maior iliquidez ${ }^{103}$.

Da mesma forma, a volatilidade da própria taxa de retorno indica incerteza. Os autores trabalham com a assunção de uma microestrutura de mercado na qual um custo informacional mais alto, implica maior custo de inventório. Assim, apesar de não haver indicação empírica deste argumento, yield volatility pode ser usado como proxy, sempre que considerado que a incerteza potencializa os custos dos agentes de mercado.

De modo semelhante, argumenta-se que a dispersão da taxa de retorno, ou a forma pela qual os agentes de mercado percebem o valor de uma debênture, tendo em vista argumentos alheios aos ativos propriamente ditos,

${ }^{103}$ SARIG, Oded; WARGA, Arthur. Bond price data and bond market liquidity. Journal of Financial and Quantitative Analysis. Seattle, v.24, n.3, p.367-378, 1989. 
afeta o preço do produto, e consequentemente causa iliquidez, frente à incerteza. Todavia, tal modelo é pouco usual, e, portanto, não há evidência concreta de sua relação com a liquidez.

HOUWELING, MENTINK e VORST trazem, ainda, outras métricas, que, contudo, podem ser reduzidas ao exposto acima. Nesse sentido, cita-se o número de indivíduos no mercado, preços não disponíveis e coupon.

Nota-se, entretanto, que o proxy mais usual para controle de liquidez é o bid-ask spread, conforme proposto por AMIHUD e MENDELSON ${ }^{104}$. Esse corresponde à diferença de preço de compra e venda praticado no mercado. Assim, o preço do lado da venda (ask) incluiria um prêmio pela venda imediata, enquanto o preço de compra (bid) englobaria uma concessão pela compra instantânea.

Nesse sentido, o bid-ask spread, por corresponder à soma do prêmio de compra e a concessão de venda, seria uma medida natural de iliquidez. Um spread maior representaria, dessa forma, um mercado menos líquido.

É evidente, portanto, em um modelo de mercado no qual se considerem agentes racionais, que negociam com o intuito de maximizar suas respectivas utilidades, que a liquidez afetará o preço de um ativo, sempre que for exigido, no momento da compra ou venda, uma compensação adicional por carregar o produto. Nestes termos, o efeito da liquidez no preço seria uma função de desconto entre o custo de liquidez futuro de um ativo a valor presente.

\section{III.1.2. Evidências de lliquidez no Mercado Secundário de Debêntures no Brasil}

À medida que se examina o impacto da liquidez no preço dos ativos, fazse necessário o estudo sobre a liquidez no mercado secundário de debêntures no Brasil. Nesse ponto, apesar de poucos estudos empíricos terem sido

104 AMIHUD, Yakov; MENDELSON, Haim. Asset pricing and the bid-ask spread. Journal of Financial Economics, Rochester, v.17, n.2, p.223-250, Dec. 1986. 
realizados sobre o tema, em comparação com o mercado acionário, a literatura disponível ilustra bem a questão.

De partida, o primeiro estudo que se tem nota no Brasil foi realizado por SHENG e SAITO ${ }^{105}$. Nesse estudo, os autores utilizaram a abordagem proposta por HOUWELING, MENTINK e VORST, para identificar proxies de liquidez no mercado secundário de debêntures no Brasil.

Os autores notam a impossibilidade da utilização de algumas proxies no mercado de dívida brasileiro, dado a indisponibilidade de certas informações à época. Logo, foram utilizadas como variáveis: o número de dias de transação, número de transações, volume relativo de transações ${ }^{106}$, diferença entre preços mínimos e máximos ${ }^{107}$ - sendo essas consideradas medidas de liquidez; e rating, tamanho da emissão, prazo, tipo de emissor, listagem na Bovespa e idade - consideradas proxies.

A amostra foi composta a partir de emissões no período de janeiro de 1999 a junho de 2002, coletadas no Sistema Nacional de Debêntures e Bovespa Fix. O período de transações selecionado é o de 18 (dezoito) meses contados a partir da data de emissão. Foram somente utilizadas emissões indexadas a taxa DI ${ }^{108}$ e IGP-M ${ }^{109}$, dado serem as mais utilizados à época. No total, foram analisadas 135 (cento e trinta e cinco) emissões, correspondendo a $75 \%$ das emissões registradas na CVM.

Como conclusão, os autores relatam que, no mercado brasileiro, apenas o tamanho da emissão e o tipo de emissor podem ser considerados proxies de liquidez, dado que afetam todas as medidas de liquidez. Rating de crédito e prazos não foram considerados proxies, uma vez que só afetam a diferença entre preços mínimos e máximos.

\footnotetext{
${ }^{105}$ SHENG, Hsia Hua.; SAITO, Richard. Liquidez das debêntures no mercado brasileiro. Revista de Administração da USP. São Paulo, v.43, n.2, p.176-185, abr./maio/jun. 2008.

106 Volume médio acumulado em um dado período.

${ }^{107}$ A informação do bid-ask spread no mercado de debêntures brasileiro era inacessível à época, dado que os autores utilizaram a informação disponível, qual seja a diferença entre preços mínimos e máximos, como equivalente.

108 Taxa de depósitos interbancários

109 Índica Geral de Preços - Mercado
} 
GONÇALVES e SHENG analisaram a hipótese de existência de prêmio de liquidez no mercado secundário de debêntures no Brasil. Nesse sentido, de acordo com a proxy ${ }^{110}$ utilizada, apontaram a variação de 8 a 30 basis points, no prêmio de liquidez, confirmando a sua existência ${ }^{111}$.

Segundo apontado, o risco de liquidez seria um risco suportado pelo investidor, afetando o spread do papel de renda fixa. Para embasar esta premissa, constrói-se, neste estudo, duas carteiras mutuamente excludentes, submetidas a dois modelos, variando segundo o proxy e o yield to maturity.

GIACOMONI e SHENG realizam estudo semelhante ao anterior, utilizando, porém, o retorno esperado como referência da expectativa dos investidores sobre o prêmio de liquidez ${ }^{112}$. Contudo, substituindo yield to maturity por retorno esperado, aponta-se uma significância reduzida ao risco de liquidez no preço das debêntures, sendo 1,9 basis point para cada 100 basis points de incremento no spread de compra e venda; 0,5 basis point para um aumento de $1 \%$ no valor do valor nominal de emissão; e 0,17 basis points para cada menos 1.000 debêntures emitidas ${ }^{113}$.

A COMISSÃO DE VALORES MOBILIÁRIOS aborda de forma quantitativa a liquidez no mercado secundário de debêntures, utilizando medidas como giro mensal e número de negócios diários por papel ${ }^{114}$. Foi apontado uma média de 0,4 e 0,1 operações por dia e por título, respectivamente, valor significativamente baixo se comparado com Israel, mercado de médio porte e um dos mais líquidos do mundo, que apresenta 10,4 e 32,0 negociações diárias de janeiro de 2009 a maio de 2010. Todavia,

\footnotetext{
${ }^{110}$ Foram utilizadas como proxy: o volume de emissão, idade da emissão, número de transações no dia e spread de compra e venda.

111 GONÇALVES, P.E.; SHENG, H.H. O apreçamento do spread de liquidez no mercado secundário de debêntures. Revista de Administração (RAUSP), São Paulo, v.45, n.1, p.30-42. Março. 2010.

112 GIACOMONI, Bruno Hofheinz; SHENG, Hsia Hua. O Impacto da Liquidez nos Retornos Esperados das Debêntures Brasileiras. Revista de Administração (FEA-USP). São Paulo, v. 48, p. 1-20, 2013.

${ }^{113}$ De todo modo, ao que se relata, a diferença de resultados pode ser decorrente de uma questão de amostragem, haja vista que os estudos não foram conduzidos sobre o mesmo grupo de debêntures. ${ }^{114}$ COMISSÃO DE VALORES MOBILIÁRIOS. O mercado de dívida corporativa no Brasil: Uma análise dos desafios e propostas para seu desenvolvimento. Rio de Janeiro: CVM, 2019
} 
o estudo apresenta evidências de melhora na liquidez no mercado secundário, como pode-se observar no Gráfico 7.

Gráfico 7 - Giro Médio Mensal das Debêntures

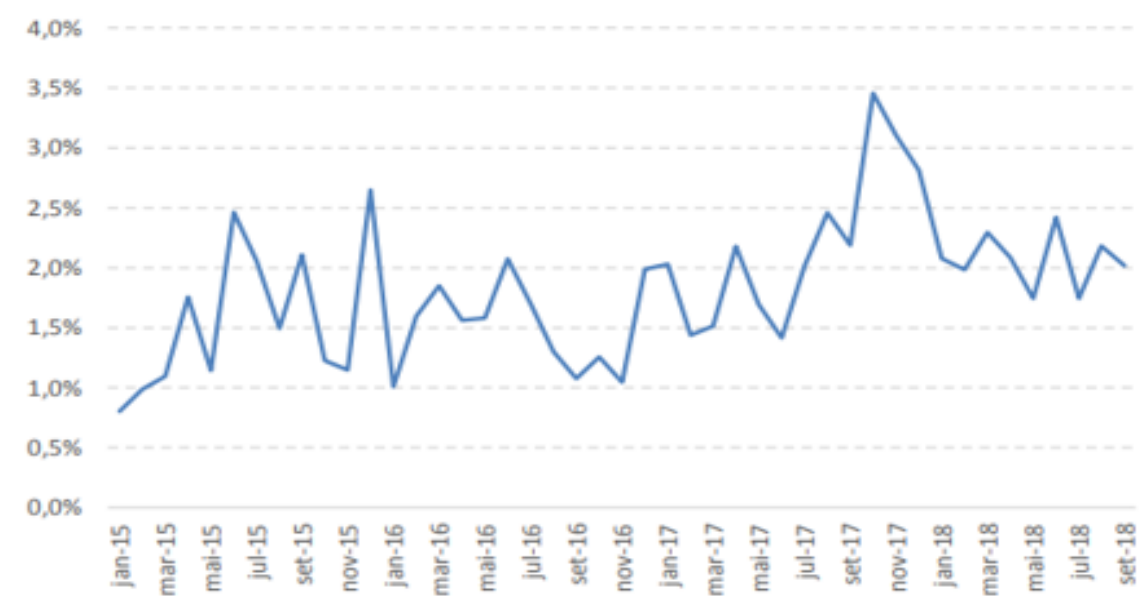

Fonte: Comissão de Valores Mobiliários

Outro ponto relevante abordado é a diferença de liquidez entre as debêntures incentivadas e as demais debêntures. Conforme demonstrado estatisticamente (Gráfico 8), a maior negociação de debêntures incentivadas pode significar um público alvo mais abrangente, que inclui investidores não residentes e pessoas físicas, atraídas pelo benefício fiscal.

Gráfico 8 - Comparativo do Giro Médio Mensal de Debêntures Incentivadas e Demais

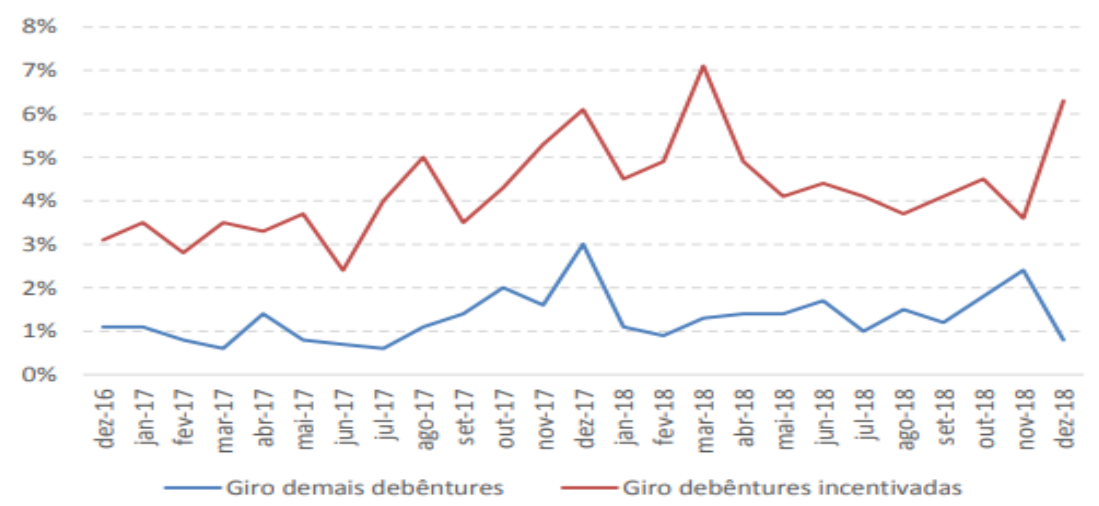

Fonte: Comissão de Valores Mobiliários

Dessa forma, ainda que GONÇALVES, SHENG e GIACOMONI tenham apresentados conclusões diferentes acerca do impacto do risco de liquidez no 
apreçamento das debêntures, há reporte na literatura sobre o tema. Assim, pelo que se relata, pode-se observar uma melhora no cenário geral, porém, em um comparativo internacional, nota-se uma necessidade de melhora do Brasil.

\section{III.1.3. Comparativo com o Mercado Israelense}

Conforme se expôs acima, existem evidências de que o risco de liquidez é um custo suportado por investidores no mercado secundário de debêntures no Brasil. Dado essas características, em comparativo internacional, nota-se que Israel possui mercado significativamente mais desenvolvido, sendo categorizado como um dos mais líquidos do mundo. Nesse ponto, o comparativo com o mercado israelense torna-se relevante, uma vez que a relação entre o PIB e o volume do mercado é semelhante ao Brasil. Não obstante, Israel apresenta níveis de liquidez significativamente mais expressivos.

Em estudo realizado em 2011, a OCDE abordou algumas características do mercado de capitais israelense. Nesse caso, destaca que, em Israel, os bancos são atores ativos, sendo sua clientela em grande parte investidores institucionais e de grande porte.

Considerando o mercado de dívida, títulos públicos representam a maior parte dos títulos emitidos, em semelhança ao caso brasileiro. Nota-se que o país passou por período de alta inflação na década de 70 , tendo envidado esforços no período em sequência para conter eventuais danos decorrentes do descontrole de preços. A partir de 2006, contudo, o governo iniciou uma série de reformas, com o intuito de modernizar os sistemas de negociação e controlar a dívida pública. Dentre essas reformas, o estudo destaca:

"In 2006, the Government Debt Management Unit launched the Primary Dealers reform. The Unit appointed 17 local and foreign Primary Dealers who accepted a commitment to quote bid and ask prices for government bonds in a new trading system for several hours daily at predetermined spreads. Primary Dealers also committed to maintain a minimum volume of purchases in government bond auctions over the year. In return, Primary Dealers enjoy access to designated bond auctions. Further, they enjoy the option of an additional allocation at the average price of the auction ("green 
shoe") on the day following the auction, access to the repo facility established by the Ministry of Finance in order to help them comply with their quoting commitments and exclusive access to the new designated inter-dealer trading system. The reform brought about a significant increase in turnover of government bonds. The average daily turnover rose from 1.1 billion NIS in 2005 to 1.7 billion in 2006 NIS and 3.2 billion NIS in 2007. Further, this reform reduced the liquidity premium, attracted new investors to the market, reduced the Government's funding costs, caused a reduction in concentration in the Israeli capital market and promoted an expansion of activity by foreign banks in the Israeli capital market." 115

Nesse cenário, o mercado de dívida corporativa se beneficiou da melhora na infraestrutura operacional, apresentando crescimento que reflete condições favoráveis de mercado. Destaca-se que o nível de crédito bancário manteve-se estagnado, o que movimentou a procura por financiamento privado.

PROTNICK e GUR-GERSHGOREN analisam a liquidez no mercado de dívida israelense. Inicialmente, ponto interessante é que, ao contrário de boa parte das jurisdições analisadas pela IOSCO, em que as negociações são bilaterais realizadas em mercado de balcão, a maior parte do volume de dívida negociada em Israel advém da Tel Aviv Stock Exchange's (TASE) eletronic order book (LOB), que tem funcionamento equivalente aos sistemas eletrônicos de negociação de ação nos mercados globais ${ }^{116}$. Assim, em Israel, negociam-se bonds em bolsa e balcão, contudo com volume majoritariamente de bolsa, conforme se evidencia no Gráfico 9.

115 ORGANISATION FOR ECONOMIC CO-OPERATION AND DEVELOPMENT. Israel: Review of the Financial System. Setembro: OECD, 2011.

116 PROTNICK, Dustin; GUR-GERSHGOREN, Gitit. Corporate Bond Market Liquidity in Israel at Heterogeneous Trade Sizes. Koret-Milken Institute Fellows Program. Israel, v. 37, p. 1-49, 2011. 
Gráfico 9 - Volume de Mercado por Segmento de Negociação

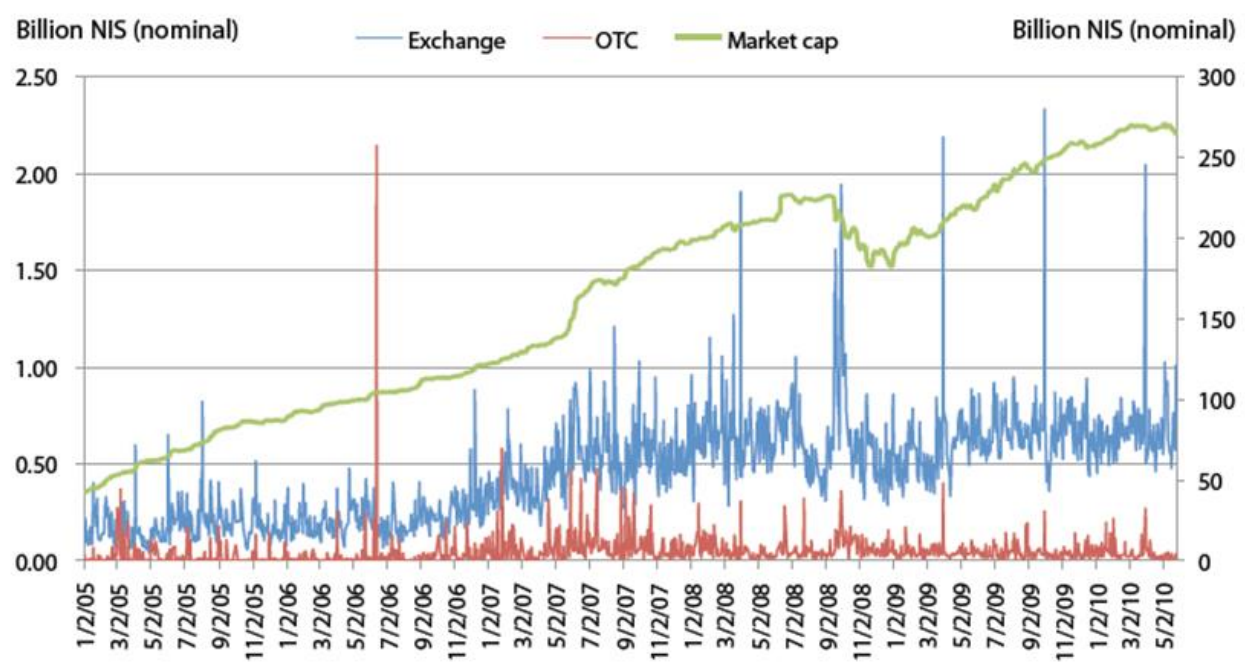

Fonte: PROTNICK, Dustin; GUR-GERSHGOREN, Gitit

Da mesma forma, pode-se notar que bonds no mercado israelense são negociados em frequência superior a ações (Gráfico 10). Os dados apresentados pelo estudo relatam que $81,3 \%$ dos bonds disponíveis são negociados em um dia médio da TASE.

Gráfico 10 - Contagem Diária de Transações na TASE (Jan-09 a Maio-10)

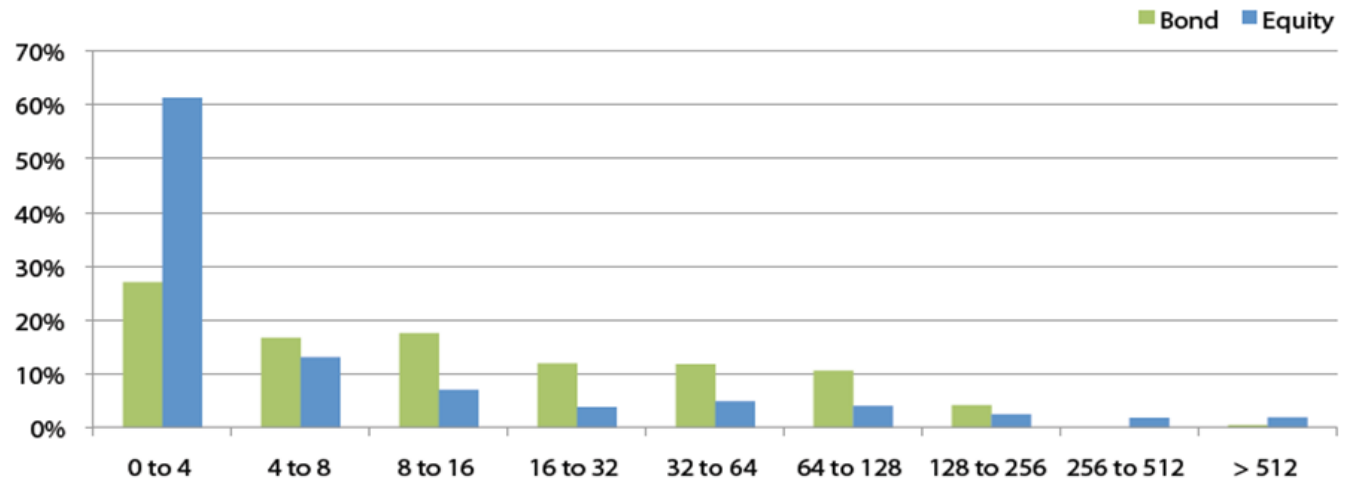

Fonte: PROTNICK, Dustin; GUR-GERSHGOREN, Gitit

O estudo dirigido pela COMISSÃO DE VALORES MOBILIÁRIOS, ao comentar o mercado israelense, menciona a existência de 29 índices de renda fixa corporativa, tendo sete estreados em 2017 - e que não afetam os dados acima. Comenta, ainda, algumas questões regulatórias relevantes, como a possibilidade de submissão do emissor ao Israel Securities Authority (ISA), em caso de dupla listagem em Israel e Estados Unidos ou Inglaterra, o que permite a padronização do envio de informações periódicas, e o uso do 
prospecto de reserva (prateleira), válido por dois anos contado de sua aprovação, o qual facilita emissões subsequentes que necessitam somente fazer remissão ao prospecto de reserva.

Dessa forma, ainda que de difícil estimativa a causa precisa do desenvolvimento de um mercado de dívida corporativa em Israel, o estudo das características desse mercado é relevante para o Brasil, tendo em vista o fortalecimento do mercado interno. Dentre as lições israelenses, destacam-se alguns procedimentos regulatórios mais céleres, como o prospecto de reserva, que poderiam ser implementados no Brasil, de modo a estimular a emissão de debêntures, e diminuir custos de transação. 


\section{III.2. Financiamento de Pequenas e Médias Empresas}

Em que pese a necessidade de alternativas de financiamento por parte de companhias brasileiras, torna-se relevante o estudo do acesso ao mercado de debêntures por parte de pequenas e médias empresas ("PME"), dado que constitui alternativa à dependência de financiamento bancário. Nesse ponto, visto a ausência de uma classificação específica do que se designa como PME, no Brasil, faz-se necessário, como será analisado abaixo, um comparativo internacional, de modo a conceituar-se a experiência exterior.

Em esforços recentes, sobre outros assuntos que não propriamente o acesso ao mercado de dívida, foi editada a Instrução CVM n ${ }^{\circ}$ 588, de 13 de julho de 2017 (“ICVM 588/17”), a qual disciplina a emissão de valores mobiliários por empresas de pequeno porte, realizada com dispensa de registro. Contudo, quanto a esse movimento, cabe a conceituação específica como crowdfunding, não tendo relação propriamente dita com o mercado de debêntures.

Aproveita-se, ainda, da ICVM 588/17, a noção de pequena empresa (exclusa a empresa de médio porte). Dessa lógica, nota-se que empresa de pequeno porte seria aquela devidamente constituída no Brasil, cuja receita bruta anual não ultrapasse $\mathrm{R} \$ 10.000 .000,00$ (dez milhões de reais), no exercício social anterior à oferta.

Como possível classificação, da mesma forma, interessante é a noção que se extrai da Instrução CVM n 578 , de 30 de agosto de 2016 ("ICVM 578/16"). Nessa linha, ao classificar a ideia de "Fundo de Investimento em Participações - Capital Semente", ressalta-se que esse seria o fundo cujas sociedades investidas tenham receita bruta anual de até $\mathrm{R} \$ 16.000 .000,00$ (dezesseis milhões reais).

Confirma-se a necessidade de meios de acesso ao mercado de debêntures, ainda, por pequenas e médias empresas, em leitura ao Projeto de Lei de Conversão $\mathrm{n}^{\circ}$ 17, de 2019. Neste, que foi promulgado sob a forma da Lei da Liberdade Econômica, incluía proposta de modificação do artigo 1.055, do 
Código Civil, permitindo a emissão de debêntures por sociedades limitadas (“\$ $4^{\circ}$ A sociedade limitada pode emitir debêntures em oferta privada, que conferirão aos titulares direito de crédito, nas condições estabelecidas na escritura de emissão e, se houver, do certificado").

As sociedades limitadas, dessa forma, em geral, são meios de associação empresarial mais comuns, e constituem a forma societária usual de empresas em estágio inicial, e de porte reduzido, como as start-ups. De todo modo, não obstante o movimento legislativo, a redação não prosperou, sendo alterada na versão sancionada.

Nota-se, assim, na experiência europeia grande contribuição sobre o tema. Tal fato deve-se, em larga medida, conforme se analisará abaixo, em razão de as economias europeias serem amplamente compostas por PMEs. Dessa forma, alterações no nível de financiamento bancário tem repercussões mais sensíveis, como demonstra estudo conduzido por NASSR e WEHINGER, e publicado pela OCDE:

\begin{abstract}
"In the years since the crisis, the credit transmission channel in a number of jurisdictions has been impaired as regards quantity, price and distribution of credit. The effects of such malfunctioning are particularly felt by small and medium-sized enterprises (SMEs), especially in Europe. Being heavily reliant on traditional bank lending, SMEs are faced with important financing constraints in an environment characterised by widespread bank deleveraging. As credit sources tend to dry up more rapidly for small firms than for large companies during economic downturns, broadening the range of non-bank debt financing instruments for SMEs should help to make them more resilient to financial shocks. Given SMEs' importance in all economies, this is also essential for economic recovery from the current economic and financial crisis." 117
\end{abstract}

Nesse quadro, como se descreverá abaixo, a experiência internacional é interessante, uma vez que enriquece a discussão sobre o tema. Dessa forma, examina-se o caso italiano (item II.1), e a experiência da Alemanha (item II.2). Em ambos os países, foram adotados regimes de estímulo à emissão de Mini Bonds - nome pelo qual ficaram conhecidos os bonds emitidos por

117 NASSR, Iota Kaousar; WEHINGER, Gert. Unlocking SME Finance through Market-Based Debt: Securitisation, Private Placements and bonds. OECD Journal: Financial Market Trends Volume 2014/2. França: 2015. p, 2. 
PMEs. Não obstante, conforme será analisado, foram observados resultados diferentes nos dois países.

\section{II.2.1. Os Mini Bonds Italiano}

Inicialmente, convém destacar o contexto em que surgiram os chamados mini-bonds ${ }^{118}$ italianos $^{119}$. Deve-se menção, dessa forma, ao D.L. 83, de 22 de junho de 2012, conforme chamado de "Decreto Sviluppo", posteriormente convertido em lei, o qual inaugurou o regime de emissão de títulos de dívida por PMEs ${ }^{120}$.

À época em que o Decreto foi editado, assim, a Itália vivia uma crise de escassez de crédito bancário (credit crunch), em sequencia à crise financeira americana e suas repercussões na Europa. Esse cenário, particularmente no caso italiano, teve um impacto econômico significativo, dado que o país dependia em larga escala de PMEs.

De modo a ilustrar a questão, dessa forma, nota-se que a Itália possuía, em dados de 2010, 4,4 milhões de empresas extra-agriculturais, sendo que 99,9\% dessas eram constituídas sob a forma de PMEs. Ainda, geravam $81 \%$ dos empregos totais do país, o que por si só deixa evidente sua importância ${ }^{121}$.

Nesse contexto, em certa medida, a estrutura das PMEs italianas pode ser considerada vulnerável, visto que são caracterizadas como dependentes de crédito bancário e compostas majoritariamente por dívida de curto prazo e

\footnotetext{
${ }^{118}$ Mini-bonds não é um termo propriamente técnico, porém é a forma que ficou conhecida essa modalidade de emissão na Itália.

119 "Mini-bonds is intended as debt instruments issued by firms on the securities market, and subscribed by qualified and institutional investors, which offers a contractually stipulated remuneration by means of periodical coupon" PREMOLI, Gianluca; TUNESI, Edoardo. The MiniBond Market in Italy: Do Small Firms Raise Capital to Increase Investments or to Refinance Debt? Politecnico di Milano. Dissertação de Mestrado. Itália: 2017. p, 88.

120 "La ricerca condotta annualmente dall'Osservatorio Mini-Bond considera i titoli obbligazionari (di qualsiasi scadenza) e le cambiali finanziarie emessi dalle imprese italiane, con un focus su quelle di piccola-media dimensione. Le normative di riferimento sono contenute nel Decreto Legge 22 giugno 2012 n. 83 ("Decreto Sviluppo") e nelle successive integrazioni e modifiche apportate dal D.L. 18 ottobre 2012 n. 179 ("Decreto Sviluppo Bis"), dal D.L. 23 dicembre 2013 n. 145 (piano "Destinazione Italia") e nel D.L. 24 giugno 2014 n. 91 ("Decreto Competitività")." POLITECNICO MILANO. Osservatorio Mini-Bond: $5^{\circ}$ Report italiano sui Mini-Bond. Milão: Fevereiro, 2019. p, 11.

${ }_{121}$ PREMOLI, Gianluca; TUNESI, Edoardo. The Mini-Bond Market in Italy: Do Small Firms Raise Capital to Increase Investments or to Refinance Debt? Politecnico di Milano. Dissertação de Mestrado. Itália: 2017. p, 31.
} 
baixo nível de investimento. Assim, o pobre funcionamento de um dos eixos, qual seja o crédito bancário, tornou necessário a busca por inovação e outras modalidades de financiamento.

Nessa linha, o Decreto Sviluppo alterou a lógica de crédito na Itália, na medida em que eliminou qualquer limitação em relação à estrutura de capital das PMEs (nível de endividamento), possibilitando maior alavancagem. Ainda, no mesmo racional, introduziu uma nova disciplina de emissão de bonds, em se tratando de sociedades com mais de 10 (dez) empregados, e faturamento total acima de $€ 2.000 .000,00$ (dois milhões de euros) ${ }^{122}$. A emissão é caracterizada por um limite de $€ 500.000 .000,00$ (quinhentos milhões de euros).

Essa dinâmica, assim, é marcada pelo alinhamento fiscal aplicado às companhias não listadas, que possibilitou a dedução das despesas de colocação e pagamento de juros, relacionado a oferta, do imposto de renda, e isenção de retenção de juros e rendimentos pagos a determinados investidores. Da mesma forma, possibilitou-se a securitização dos minibonds. Pela natureza do ativo, se limitou suas subscrição aos investidores profissionais $^{123}$. Conforme descrevem NASSR e WEHINGER:

\begin{abstract}
"The legislation lifted the previously penalising tax treatment of bond issuance by unlisted companies relative to listed ones, aligning the rules on tax deductibility of interest expense of the two respective types of firms. In relation to the tax applying to investors in such instruments, the exemption from the $20 \%$ withholding tax on interest on debt issued by listed companies was extended to debt issued by unlisted companies, provided that such debt is traded on regulated markets or multilateral trading facilities (Freshfields, 2012)."124
\end{abstract}

É interessante, ainda, notar que o Decreto Sviluppo possibilitou que empresas de seguro investissem em mini-bonds, e fundos investidores nestes títulos, como ativos constituintes de suas reservas de capital, o que, em certa

\footnotetext{
${ }^{122}$ Nesse ponto, nota-se que o Decreto excluiu sociedades bancárias e aquelas com menos de 10 (dez) funcionários da lógica de emissão de mini-bonds.

${ }^{123}$ COMISSÃO DE VALORES MOBILIÁRIOS. O mercado de dívida corporativa no Brasil: Uma análise dos desafios e propostas para seu desenvolvimento. Rio de Janeiro: 2019. p, 54.

${ }^{124}$ NASSR, Iota Kaousar; WEHINGER, Gert. Unlocking SME Finance through Market-Based Debt: Securitisation, Private Placements and bonds. OECD Journal: Financial Market Trends Volume 2014/2. França: 2015. p.168.
} 
medida, cria demanda pelo ativo. Quanto aos bancos, facilitou-se a utilização de mini-bonds como colateral, em se tratando de emissões de dívida.

A inovação legislativa, nesse sentido, foi seguida pela modernização da infraestrutura de mercado. Assim, em 2013, foi inaugurado um segmento na Borsa Italiana, destinado à negociação de mini-bonds e outros ativos, por investidores profissionais, no qual permitia-se companhias não listadas negociar títulos de dívida. Tal segmento foi chamado de ExtraMOT PRO, ramificação profissional do ExtraMOT ${ }^{125}$. Para negociação nesse segmento, as companhias emissoras devem publicar prospecto ou documento admissional, nos quais deverão constaros riscos envolvendo a emissão, as informações sobre a emissora e as características do ativo. Da mesma forma, requer-se que a emissora publique, no mínimo, dois balanços, ou demonstração de resultado, se existente.

Dessa forma, em estudo estatístico realizado pelo POLITECNICO DI MILANO, nota-se um padrão de evolução no mercado de mini-bonds italiano. Conforme se observa no Gráfico 11, o número de emissões totalizava 746 em dezembro de 2018:

125 "Il mercato ExtraMOT PRO nasce nel febbraio 2013 come segmento professionale del mercato ExtraMOT di Borsa Italiana (si veda la Figura 1.8) in cui possono essere quotati project bond, obbligazioni, cambiali finanziarie, asset backed securities (ABS) e strumenti partecipativi." POLITECNICO MILANO. Osservatorio Mini-Bond: $5^{\circ}$ Report italiano sui Mini-Bond. Milão: Fevereiro, 2019. p, 17. 
Gráfico 11 - Contagem Diária de Transações na TASE (Jan-09 a Maio-10)

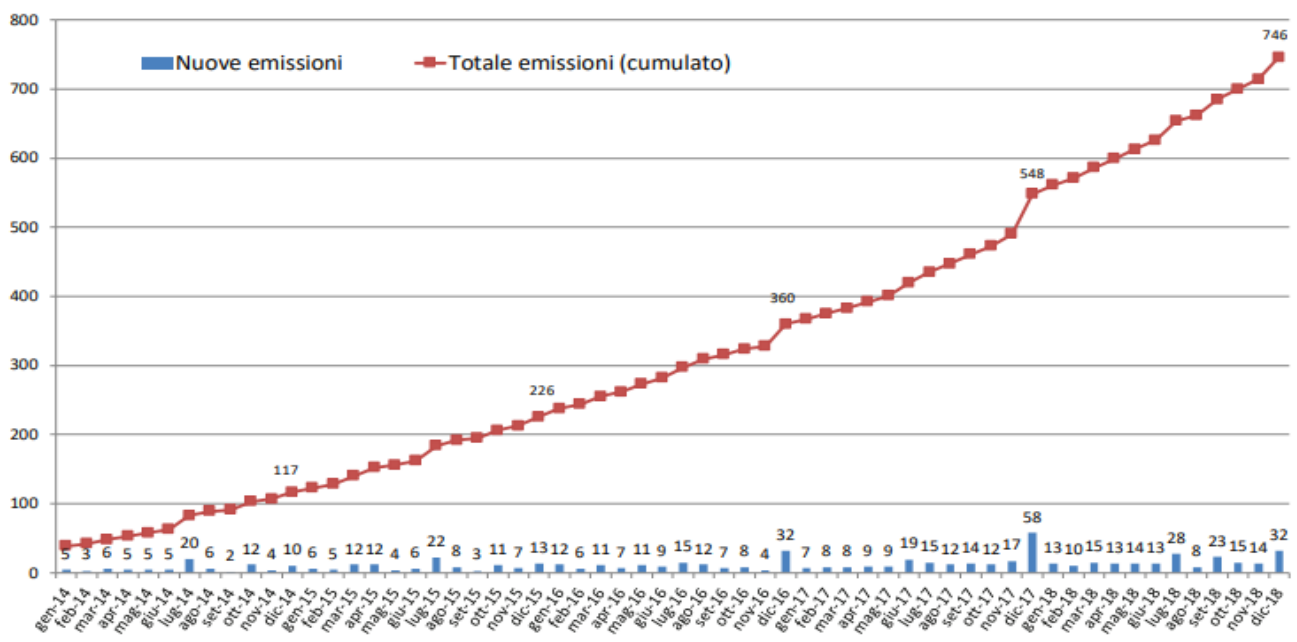

Fonte: Politecnico di Milano

Ressalta-se, ainda, conforme o estudo, que o montante total acumulado, exclusivamente em emissões de PMEs, totaliza $€$ 4.656.000.000,00 (quatro bilhões seiscentos e cinquenta e seis milhões de euros). Ainda, cerca de $54 \%$ das emissões apresentavam valor inferior a $€ 5.000 .000,00$ (cinco milhões de euros), sendo a duração média dos ativos de 5,3 $\operatorname{anos}^{126}$.

A COMISSÃO DE VALORES MOBILIÁRIOS, ao analisar o mercado italiano, cita que os títulos de dívida privada receberam estímulo com a criação do Fondo Italiano d'Investimento $S G R^{127}$. Esse, constitui mecanismo para aplicação em outros fundos, aplicadores em títulos emitidos por PMEs. Na mesma linha, as PMEs contam com o auxílio de Fundo de Garantia para PMEs, cujo objetivo é acessar recursos via mecanismos de crédito.

Assim, nota-se, no caso italiano, uma experiência de sucesso. Pode-se argumentar, nesse ponto, que o estímulo à participação do mercado de

126 POLITECNICO MILANO. Osservatorio Mini-Bond: $5^{\circ}$ Report italiano sui Mini-Bond. Milão: Fevereiro, 2019. p, 42-45.

127 "Os fundos de dívida privada italianos ganharam grande impulso com a decisão do Fondo Italiano d'Investimento SGR, entidade controlada pelo Ministério das Finanças italiano e instituições bancárias italianas, de constituir um fundo específico para investir em outros fundos ou veículos aplicadores em instrumentos de dívida de PMEs. O Fondo Italiano d'Investimento SGR realizou, por meio de outros fundos, 80 operações com 60 empresas e com investimento médio de EUR 6,5 milhões. Alguns dos primeiros fundos que participaram do nascimento do mercado de mini-bonds encerraram as atividades e retornaram os recursos aos investidores em 2017, enquanto outros veículos realizaram captações e novos fundos foram constituídos, demonstrando o dinamismo desse mercado." COMISSÃO DE VALORES MOBILIÁRIOS. O mercado de dívida corporativa no Brasil: Uma análise dos desafios e propostas para seu desenvolvimento. Rio de Janeiro: 2019. p, 55 . 
capitais, no financiamento de empresas, tem como fundamento a dependência econômica do país à estrutura de PMEs. Dessa forma, o movimento legislativo decorrente do Decreto Sviluppo obteve êxito em inaugurar formas de financiamento alternativas às PMEs.

\section{II.2.2. As Mittelstand: $O$ caso alemão}

Mittelstand é o termo utilizado para se designar pequenas e médias empresas na Alemanha ${ }^{128}$. Dessa forma, o mercado de dívida emitida por PMEs, no caso alemão, constitui segmentos de negociação de renda fixa, iniciados por volta de $2009^{129}$. A maior novidade, nesse caso, foi a redução do volume mínimo de emissão de $€ 100.000 .000,00$ (cem milhões de euros) para $€ 10.000 .000,00$ (dez milhões de euros) e a simplificação dos requisitos do prospecto. Assim, nota-se que, entre 2011 e 2012, o mercado teve significativo crescimento, totalizando cerca de 40 (quarenta) emissões anuais ${ }^{130}$.

De todo modo, ao que indica a literatura, ao contrário do caso italiano, o modelo alemão falhou no desenvolvimento de um mercado de longo prazo para títulos emitidos por PMEs. Desse fato, se reporta o alto número de defaults das companhias emissoras.

Em contradição ao que se estabeleceria em teoria, assim, segundo a qual investidores teriam a capacidade de prever a probabilidade de insolvência, e exigir compensação adicional pelo risco, a experiência alemã não verificou tal hipótese. Como explicação, pode-se conceber uma superestimação das companhias emissoras por partes de agências de classificação e

\footnotetext{
128 AUDRETSCH, David; ELSTON, Julie Ann. Financing the Mittelstand. Small Business Economics 9. Holanda: Kluwer Academic Publishers, 1997. p, 1.

${ }^{129}$ FEIHLE, Patrick Christian; LAWRENZ, Jochen. The Issuance of German SME Bonds and its Impact on Operating Performance. Schmalenbach Business Review. Austria: 2017. p, 1.

${ }^{130}$ Há evidências na literatura de que o valor nominal baixo das emissões atraía investidores inexperientes. "The market for German mini-bonds in 2010, a period characterized by solid economic growth. The vast majority of issuers at the time chose low nominal values of $€ 1,000$, thereby attracting uninformed and relatively inexperienced private investors, in addition to institutional investors." SCHWEIZER, Denis et al. Hidden Champions or Black Sheep? Evidence from German Mini-Bonds. Small Business Economics. Alemanha: 2016. p, 7.
} 
peculiaridades na avaliação das emissoras pelos investidores, o que possibilitou que um grande número de PMEs de baixa qualidade obtivessem financiamento.

FEIHLE e LAWRENZ, nesse contexto, analisam dados financeiros de emissoras, comparando com não emissoras, de modo a avaliar se a avaliação prévia do público investidor e das agências de rating estavam, de fato, infladas. A comparação com companhias não emissoras, assim, possibilita avaliar isoladamente o desempenho pós-emissão.

Como resultado, os autores apontam um declínio na renda líquida das companhias emissoras, após a colocação dos títulos, fato previsível em vista do pagamento dos juros relativos aos mini-bonds. Contudo, em análise mais aprofundada, foi observada uma queda, também, em indicadores operacionais como o EBTIDA (earnings before taxes, interest, depreciation and amortization), que precede o desconto de juros, e pode significar, por si só, um declínio de desempenho real, após a emissão, que não poderia ser previsto por decorrer de fatores exclusivamente operacionais.

SCHWEIZER et al., analisando o mesmo cenário, fornecem explicação quanto ao papel do rating, no alto nível de default, aparentemente imprevisível, no mercado de mini-bonds alemão ${ }^{131}$. Assim, observam que o alto nível de inadimplemento desvia da classificação inicial atribuída pelas agências classificadoras de risco ${ }^{132}$.

Em uma amostragem de 118 (cento e dezoito) emissões, os autores argumentam que as agências classificadoras tendiam, no período, a superestimar o valor das companhias, suprindo o mercado de informação imprecisa. Da mesma forma, em racional semelhante às ofertas de ações, defendem que emissoras de qualidade ruim tem estímulo a precificar-se no

\footnotetext{
131 Ibid., p. 1.

132 "The majority of mini-bond issuers were initially rated at BB and BBB levels, which suggested generally high borrower quality. This was not surprising, because these companies (the German "Mittelstand") are perceived as the backbone of the economy, and are often referred to as hidden champions." Ibid., p, 2.
} 
nível mais alto possível, enquanto boas companhias praticariam o underpricing para assinalar suas qualidade.

Fato é, nessa lógica, que narra-se um cenário em que, em comparação com a média histórica por classe de rating, há uma maior ocorrência de eventos de default. Dado esta dinâmica, questiona-se, no caso da Alemanha, se eventual dano aos investidores poderia ter sido evitado por garantias contratuais ou proteção mais rígidas. De todo modo, o exemplo da Alemanha é emblemático para a compreensão dos riscos associados a esse tipo de ativo. 


\section{Conclusão}

Portanto, pelo exposto, nota-se que o mercado de debêntures, atualmente, apresenta significativa melhoria em comparação com o histórico brasileiro, o que é um bom indicativo. Contudo, em comparação com a média global, ainda há largo espaço para desenvolvimento.

A análise de um mercado, assim, não é ciência dogmática, o que implica que diferentes aspectos, e pontos de vista, podem aparecer em uma pesquisa. Da mesma forma, não há fórmula para o crescimento. A história e a experiência são, nesse sentido, a bússola para o caminho almejado.

Fato é, contudo, que o tema requer atenção e estímulo, de modo que se alcance um resultado compatível com suas possibilidades. Como norte, a literatura, em conjunto a prática, deve investigar os fatores que afetam, limitam e fomentam os atores e participantes do mercado.

Só a partir da compreensão real do racional do mercado, é que pode-se falar em regulação bem sucedida. Caso contrário, se estaria diante de um jogo às cegas, e sem direção, a qual não é claro aonde deve-se atingir.

Dessa lógica, o presente trabalho buscou contribuir para o entendimento multidisciplinar da estrutura do mercado de debêntures, tornando às características jurídicas, financeiras e econômicas, que afetam o produto negociado. Assim, compreende-se que a debênture é um instrumento financeiro importantíssimo para a dinâmica de financiamento de longo prazo, e que seu sustento e entendimento, devem ser objeto de constante revisão. 


\section{Bibliografia}

ANDERSON, Christopher W., Financial contracting under extreme uncertainty: an analysis of Brazilian corporate debentures. Journal of Financial Economics 51. Columbia, No. 1, 45-84.

AMARAL, José Romeu Garcia do. Ensaios sobre o Regime Jurídico das Debêntures. Faculdade de Direito da Universidade de São Paulo. Dissertação de Mestrado. 2014.

AMIHUD, Yakov; MENDELSON, Haim. Asset pricing and the bid-ask spread. Journal of Financial Economics, Rochester, v.17, n.2, p.223-250, Dec. 1986.

AMIHUD, Yakov; MENDELSON, Haim. Liquidity, maturity and the yields on U.S. government securities. Journal of Finance. Nova Iorque, 46, 14111426. 1991

AMIHUD, Yakov et al. Liquidity and Asset Prices. Foundations and Trends in Finance. Nova Iorque, 2005

ARROW, Kenneth J. Approaches to the Theory of Choice in Risk-Taking Situations. Econometrica, Vol. 19. EUA, p, 404-437, 1951.

ASSAF NETO, Alexandre. Mercado Financeiro. 14 ${ }^{\mathrm{a}}$ Edição. São Paulo: Atlas, 2019

AUDRETSCH, David; ELSTON, Julie Ann. Financing the Mittelstand. Small Business Economics 9. Holanda: Kluwer Academic Publishers, 1997. 
BIAIS, Bruno; Richard Green. The Microstructure of the Bond Market in the 20th Century. Review of Economic Dynamics. Vol. 33. EUA, p. 250-271, 2019.

BORBA, José Edwaldo Tavares. Das Debêntures. Rio de Janeiro: Editora Renovar, 2005.

BRAGANÇA, Gabriel G. Fiuza. Evolução Recente do Mercado de Debêntures no Brasil: As Debêntures Incentivadas. Instituto de Pesquisa Econômica Aplicada. Rio de Janeiro: IPEA, 2015.

CARVALHO, Antonio Gledson de; MARQUES, Felipe Tumenas. The Microstructure of the Brazilian Market for Corporate Bonds. Fundação Getúlio Vargas. São Paulo: FGV, 2019.

CARVALHOSA, Modesto. Comentários à Lei de Sociedades Anônimas - $1^{o}$

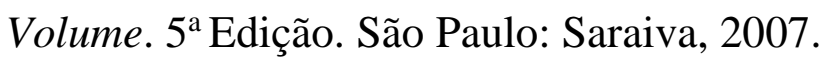

COMISSÃO DE VALORES MOBILIÁRIOS. O mercado de dívida corporativa no Brasil: Uma análise dos desafios e propostas para seu desenvolvimento. Abril: CVM, 2019

EIZIRIK, Nelson. A Lei das S/A Comentada - Volume Um. $2^{\text {a }}$ Edição. São Paulo: Quartier Latin, 2015.

EIZIRIK, Nelson. Aspectos Modernos do Direito Societário. Rio de Janeiro: Renovar, 1992.

EIZIRK, Nelson. Emissão de Debêntures. Revista dos Tribunais. São Paulo: Thompson Reuters, 1995. vol. 721, 52 - 61, p. 
JENSEN, Michael et al. The Capital Asset Pricing Model: Some Empirical Tests. In: JENSEN, Michael. Studies in The Theory of Capital Markets. Praeger Publishers Inc. Nova Iorque, vol. 1, n.4, p. 269-364. 1972.

FABOZZI, Frank J. Bond Markets, Analysis and Strategies. Prentice-Hall, Inc. $3^{\text {rd }}$ Edition. New Jersey: 1996.

FEIHLE, Patrick Christian; LAWRENZ, Jochen. The Issuance of German SME Bonds and its Impact on Operating Performance. Schmalenbach Business Review. Austria: 2017.

FILGUEIRA, Antônio Luís Lima; LEAL, Ricardo Pereira Câmara. Cláusulas de Escrituras de Debêntures Brasileiras após a Estabilização Econômica. Instituto COPPEAD de Administração, UFRJ. Rio de Janeiro, 2000 .

FISHER, Lawrence. Determinants of Risk Premiums on Corporate Bonds. Journal of Political Economy. Chicago: vol. 67, 1959.

FRANCO, Gustavo. Notas Sobre Crowding Out, Juros Altos e Letras Financeiras do Tesouro. Rio de Janeiro, 2005.

GIACOMONI, Bruno Hofheinz; SHENG, Hsia Hua. O Impacto da Liquidez nos Retornos Esperados das Debêntures Brasileiras. Revista de Administração (FEA-USP). São Paulo: v. 48, p. 1-20, 2013.

GONÇALVES, Paulo Eduardo; SHENG, Hsia Hua. O apreçamento do spread de liquidez no mercado secundário de debêntures. Revista de Administração (RAUSP), São Paulo, v.45, n.1, p.30-42. Março. 2010. 
GUIMARÃES, Francisco José Pinheiro. Debêntures. In: LAMY FILHO, Alfredo e BULHÕES PEDREIRA, José Luiz (Coor.). Direito das Companhias. 2a Edição. Rio de Janeiro: Editora Forense, 2017.

HOUWELING, Patrick et al. Comparing possible proxies of corporate bond liquidity. Journal of Banking \& Finance. Amsterdam, v.29, n.6, p.1331-1358, June 2005.

HULL, John C. Options, Futures and Other Derivatives. $9^{\text {th }}$ Edition. Inglaterra: Pearson Education Limited, 2015.

INTERNATIONAL ORGANIZATION OF SECURITIES COMMISSIONS. Development of Corporate Bond Markets in the Emerging Markets. Espanha: IOSCO, 2011.

LAMY FILHO, Alfredo e BULHÕES PEDREIRA, José Luiz (Coor.). Direito das Companhias. 2a Edição. Rio de Janeiro: Editora Forense, 2017.

LUENGNARUEMITCHAI, Pipat; ONG, Li Lian. An Anatomy of Corporate Bond Markets: Growing Pains and Knowledge Gains. IMF Working Paper WP/05/152. EUA: IMF, 2005.

NASSR, Iota Kaousar; WEHINGER, Gert. Unlocking SME Finance through Market-Based Debt: Securitisation, Private Placements and bonds. OECD Journal: Financial Market Trends Volume 2014/2. França. 2015.

ORGANISATION FOR ECONOMIC CO-OPERATION AND DEVELOPMENT. Israel: Review of the Financial System. França: OECD, 2011 
PAULA, Luiz Fernando de; FARIA JR., João Adelino de. Mercado de Títulos de Dívida Corporativa Privada no Brasil: Aspectos estruturais e evolução recente. Revista de Economia Contemporânea. Vol. 16. Rio de Janeiro, n. 1, p. 107-137, jan-abr. 2012.

POLITECNICO MILANO. Osservatorio Mini-Bond: $5^{\circ}$ Report italiano sui Mini-Bond. Milão: Fevereiro, 2019.

PROTNICK, Dustin; GUR-GERSHGOREN, Gitit. Corporate Bond Market Liquidity in Israel at Heterogeneous Trade Sizes. Koret-Milken Institute Fellows Program. Israel: v. 37, 1-49. Janeiro 2011

PEREIRA, Caio Mário da Silva. Instituições de Direito Civil - Volume IV. $25^{\mathrm{a}}$ Edição. Rio de Janeiro: Forense, 2017

PREMOLI, Gianluca; TUNESI, Edoardo. The Mini-Bond Market in Italy: Do Small Firms Raise Capital to Increase Investments or to Refinance Debt? Politecnico di Milano. Dissertação de Mestrado. Itália: 2017.

ROSS, Stephen A; Fundamentos da Administração Financeira. 9 $9^{\mathrm{a}}$ Edição. Porto Alegre: AMGH, 2013.

SAITO, Richard et al. Governança Corporativa Embutida nas Escrituras de Debêntures Emitidas no Brasil. Revista de Administração da USP. São Paulo, v.42, n.3, p. 280 - 292, jul/ago/set. 2008

SARIG, Oded; WARGA, Arthur. Bond price data and bond market liquidity. Journal of Financial and Quantitative Analysis. Seattle, v.24, n.3, p.367-378, Sept. 1989. 
SARR, Abdourahmane; LYBEK, Tonny. Measuring Liquidity in Financial Markets. IMF Working Paper WP/02/232. EUA: IMF, 2002.

SCHWEIZER, Denis et al. Hidden Champions or Black Sheep? Evidence from German Mini-Bonds. Small Business Economics. Alemanha: 2016.

SEIGNEMARTIN, Gustavo de Carvalho. The Rise of Credit Default Swaps and the Changing Political Environment of Sovereign Debt Markets. APSA 2011 Annual Meeting. Toronto, 2011

SHENG, Hsia Hua.; SAITO, Richard. Liquidez das debêntures no mercado brasileiro. Revista de Administração da USP. São Paulo, v.43, n.2, p.176185, abr./maio/jun. 2008.

SIMON, Herbert A. A Behavioral Model of Rational Choice. The Quarterly Journal of Economics, vol. 69. EUA: MIT Press, 1955.

TORRES FILHO, Ernani Teixeira; MACAHYBA, Luiz. O Elo Perdido. $O$ Mercado de Títulos de Dívida Corporativa no Brasil: Avaliação e Propostas. São Paulo: Instituto de Estudos para o Desenvolvimento Industrial IEDI/Instituto Talento Brasil, 2012.

YAZBEK, Otávio. Crise, inovação e regulação no mercado financeiro considerações sobre a regulamentação do mercado de derivativos de balcão. In: Mercado de Capitais. SOUZA JÚNIOR, Francisco Satiro de (Coords.). São Paulo: 2013.

YAZBEK, Otávio. O Risco de Crédito e os Novos Instrumentos Financeiros. In: WAISBERG, Ivo; FONTES, Marcos Rolim Fernandes (Coords.). Contratos Bancários. São Paulo: Editora Quartier Latin, 2006. 330, p. 
YAZBEK, Otávio. Regulação do Mercado Financeiro e de Capitais. Rio de Janeiro: Elsevier, 2017.

YAZBEK, Otávio. A Modernização do Regime das Debêntures e a criação de um Mercado de Dívida de Longo Prazo no Brasil. In: Direito Empresarial e Outros Estudos em Homenagem ao Professor José Alexandre Tavares Guerreiro. CASTRO, Rodrigo R Monteiro de et al. São Paulo: Quartier Latin, 2013, p. 565-589 